\title{
Effect of Priming on Seed Quality of Soybean [G/ycine max (L.) Merrill] Varieties at Assosa, Western Ethiopia
}

\author{
Meseret Ejeta \\ Department of Seed Science and Technology, Holetta Agricultural Research Center, Ethiopian Institute of Agricultural Research, Addis \\ Ababa, Ethiopia
}

Email address:

ejetameseret@gmail.com

To cite this article:

Meseret Ejeta. Effect of Priming on Seed Quality of Soybean [Glycine max (L.) Merrill] Varieties at Assosa, Western Ethiopia. Science Research. Vol. 8, No. 3, 2020, pp. 59-72. doi: 10.11648/j.sr.20200803.11

Received: October 14, 2019; Accepted: November 26, 2019; Published: April 28, 2020

\begin{abstract}
Benishagul state of Ethiopia is a potential place for soybean seed production but, seed quality production is the major problem under this place. So that, the use of seed priming techniques before seed sowing has been the best solution to overcome seed quality problem. Experiment was carried out at Haramaya University seed science laboratory. The objective of the experiment was to determine the effect of priming on seed quality of soybean varieties. The experiment had three varieties (Belessa95, Wello and Gishama), three priming types [GA 3 (100PPM), $\mathrm{KH}_{2} \mathrm{PO}_{4}(50 \mathrm{PP})$ and water] and three priming durations $(0,6,12$ hours) were evaluated using a randomized complete block design for field experiment. Seed were harvested and seed quality analysis was tested at laboratory by using completely Randomized Design in three replications. The result of the study showed that highly significant $(\mathrm{P} \leq 0.01)$ difference between interaction of varieties by, priming type and soaking durations for Seedling dry weight, seedling vigor index-2, speed of germination, Electrical conductivity and field emergence index and significant $(\mathrm{P} \leq 0.05)$ difference for seedling vigor index-1 were observed. Varieties by priming type interaction showed highly significant $(\mathrm{P} \leq 0.01)$ difference for seedling dry weight, seedling vigor index-2, speed of germination, electrical conductivity and field emergence index. The highest shoot length were observed for Belessa95 varieties primed with $\mathrm{GA}_{3}$ $(16.31 \mathrm{~cm})$ and the highest root length were observed for Belessa95 varieties $(6.98 \mathrm{~cm})$ and seed primed with water $(7.22 \mathrm{~cm})$. The highest seedling dry weight was recorded when Belessa95 variety primed with water for $12 \mathrm{hr}(250 \mathrm{gm})$. The highest seedling vigor index 1 was recorded when Gishema variety primed with $\mathrm{KH}_{2} \mathrm{PO}_{4}$ for $6 \mathrm{hr}$ (2202.20), the highest seedling vigor index 2 was recorded when Belessa95 variety primed with water for 12hr (23673) and the highest Speed of Germination was recorded when Wello variety primed with water for $6 \mathrm{hr}$ (42.89). Colletotrichum dematium, Aspergillus flavus, Aspergillus niger, Fusarium oxysporum, Penicillium spp, Alternaria spp, Tricodormal spp, Rhizoctonia solani, Pythium spp, Cladosporium spp, Curvularia lunata, Rhizoctonia bataticola, Rhizopus spp, Macrophomina spp, yeast, Chaetomium spp, Sphacelomia glycines and Xanthomonas campestri were disease identified from seed sample. Soybean varieties primed with water and $\mathrm{GA}_{3}$ priming medias exhibited the better results in improving seed quality followed by $\mathrm{KH}_{2} \mathrm{PO}_{4}$. Hence, Water priming was recommended to user to overcome the problems of poor crop emergence and establishments under adverse environmental condition.
\end{abstract}

Keywords: Chemo-priming, Germination, Seed Health, Seed Vigor, Soybean

\section{Introduction}

Soybean [Glycine $\max$ (L.) Merrill] is a legume crop taxonomically belongs to the family leguminace, sub family Papilionaceae, tribe phaseolae, Genus Glycine and subgenus Soja [1]. Moreover, the Genus Glycine contains two subgenera, namely Glycine and Soja. The wild (G. soja) and cultivated ( $G$. max) annual species are grouped under
thesubgenusSoja. However, the chromosome number of the cultivated soybean species is adiploidtetraploid $(2 \mathrm{n}=2 \mathrm{x}=$ 40). The cultivated species; Glycine $\max$ (L.) has never been found in the wild, therefore its probable ancestor is $G$. sojawhich is the major gene sources [2]. Soybean is considered either a short or a day neutral plant requires 25 to $30^{\circ} \mathrm{C}$ temperature for growth and proper nodulation. Soybean is a medium altitude crop well adapted to altitude varying 
from 1300 to 1800 masl receiving annual rainfall of 900 to $1300 \mathrm{~mm}$ and it also well at 1900 masl having 550 to 700 $\mathrm{mm}$ annual rainfall [3]. The crop has a wide range of soil adaptation, but performs well on light textured, loams and medium black clays with $\mathrm{pH}$ range of 6.5 to 7 in Ethiopia [4]. In 2015, about 318.8 million metric tons of soybeans were produced in the world. The United States of America accounted for about $33.55 \%$ of the soybean production. The other major producers are Brazil $(31.36 \%)$, Argentina $(17.88 \%)$, China $(3.76 \%)$, Canada $(1.96 \%)$ and others account the rest (11.48\%) [5]. It is cultivated in Sub-Saharan Africa to a very limited extent [6-7]. During the last decade or so, the African continent accounted for $0.4 \%$ to $0.6 \%$ of the world's total production of soybean, the main producers being Nigeria, SouthAfrica, Zimbabwe and Rwanda. Overall, 19 African countries appear in the world soybean production. More than $90 \%$ of the soybean is produced by Nigeria (48.9\%), Uganda (16.8\%), South Africa (14.9\%), Zimbabwe (8.4\%), Ethiopia (2.7\%) and Rwanda (2.0\%). The economic viability of soybean is determined by commercial utilization of both sub products; oil, and meal, which accounts one and two third of the crop economic value, respectively. Soybean oil is dominant in the world market, accounts about $30 \%$ of the total vegetable oils. In global market, its oil share is estimated nearly $44 \%$, and ranked first among the major oil crops such as rapeseed, groundnut, and sesame [8]. Moreover, on the weight basis, soybean protein yield is about twice, four, and twelve times than that of the meat, eggs, and milk, respectively [9]. The nutritional value of soybean primarily lies in its quality protein and oil content which is free of cholesterol. The crop is a promising pulse proposed for alleviation of acute protein and oil shortage in the world. Soybean is also nutritious and healthy due to proportional composition of carbohydrate, fiber, vitamins, and minerals [10]. Studies had been showed a reduced risk of cancer, heart, and chronic disease in soybean product consumed populations [10]. The crop is also highly important in cropping system thereby enriching soil fertility through biological $\mathrm{N}$ fixation in symbiosis with bacteria better than other legume crops. On the average soybean can fix over 75 $\mathrm{kg}$ nitrogen per hectare [11]. The success of the soybean industry is attributed to the crop's agronomic performance and composition [12]. Soybean can be grown in a wide range of environments, has moderate drought tolerance, and does not require nitrogen fertilization because of symbiosis with the nitrogen fixing bacteria; Rhizobium. Roughly $60 \%$ of the dry weight of soybean seed is composed of protein and oil, and as a result soybean seed has the highest protein and second highest oil content among cereal and legume species [13]. These facts make soybean an important crop for oil manufacturing, animal feed, and food production [14-15]. Soybean is important because of its nutritional qualities. It has high percentage of high quality and cheap protein and is a rich source of edible oil. The world production of edible oils consists of $30 \%$ soybean [16]. Soybean seed contains about $40-45 \%$ protein and $20-22 \%$ oil, $20-26 \%$ carbohydrate and a high amount of $\mathrm{Ca}, \mathrm{P}$ and vitamins [17]. In Ethiopia, soybean was started in 1950's on introduced genotypes with main emphasis of identifying adapted lines for the potential areas, replacing imported soybean flour, introducing into the existing cropping systems, and diet of the poor farmers [3]. It is a crop that can play major role as protein source for resource poor farmers of Ethiopia who cannot afford animal products. In our country, now a day's soybean is highly utilized in nutrition industries for both food and feeds.

The area under soybean cultivation in Ethiopia is estimated about 35259.76 hectares (ha) and 72183.75 tons of production with the productivity of 2.04 tons ha-1 which is by far lower than the world's average of 2.3-4.0 tons ha-1 [18]. In Benishangul-Gumuz Region the area under soybean cultivation is 12939.90 hectares and productivity is 1.90 tons $\mathrm{ha}^{-1}[19]$. Soybean was introduced into Benishangul -Gumuz during resettlement program. Since then, the farmers grow soybean on small scale as sole crop primarily for its economic merit and home consumption. In Assosa zone, soybean was the most dominant pulse crop with the total production area and productivity of 3617.63 ha and 1.46 tons/ha, respectively [18]. Now a day's, soybean production is highly raised in the region due to increased demand of the farmers and investors.

Even if the region is suitable for production the use of soybean seeds of low physical and physiological quality is a common practice under this environment, leading to inadequate plant population which final reduce the production and productivity in the field. Faster germination and emergence is an important factor for better, more and uniform stand establishment. This poor crop emergence and establishments might happened due to unpredictable and erratic rain fall, low or inadequate soil nutrients, low quality seeds, hard seed coat, sowing time, low moisture contents of the soil, heat stress, limited access to mechanization and diseases of the crops like soybeans which are mainly grown under such environments all contribute to failures and poor crop stand establishment that may survive the crop poorly under such adverse environmental conditions. Under such conditions seed germinations, seed emergence and seedling establishments can be inhibited and reduced. Therefore, seed priming (seed invigoration) before seed sowing has been a best solution to overcome such adverse environmental effects for better, more and uniform seed germination, seed emergence and seedling establishment. Concerning priming treatments studies on soybean are not adequate but encouraged so more information is required to use this technology in seed production.

Hence, objectives of this study were:-

1. To determine the effect of priming on seed quality of soybean varieties.

\section{Materials and Methods}

\subsection{Description of the Study Sites}

The field experiment was conducted in Benishangul-Gumuz Regional State, at Asossa Agricultural Research Center (AsARC) on station in the 2015 main cropping season under 
rain fed field conditions. Benishangul- Gumuz Regional State is geographically located at the latitude of $9^{\circ} 30^{\prime}$ to $11^{\circ} 39^{\prime \prime} \mathrm{N}$ and longitude of $34^{\circ} 20^{\prime}$ to $36^{\circ} 30^{\prime \prime} \mathrm{E}$ covering a total land area of 50,000 square kilometer. The study site is located at $10^{\circ} 02^{\prime} 05^{\prime \prime} \mathrm{N}$ latitude and 34 $34^{\prime} 09^{\prime \prime} \mathrm{E}$ longitudes and situated east of Assosa town and west of Addis Ababa about $14 \mathrm{~km}$ and $653 \mathrm{~km}$ distance, respectively. The area experiences a unimodal rainfall pattern and has annual rainfall of about 1118 mm out of which $936.3 \mathrm{~mm}$ rain was recorded during the growing season of the crop. The rainy season occurs from March to December and the maximum rain is received in August. The minimum and maximum temperatures are $11.9^{\circ} \mathrm{C}$ and $32.7^{\circ} \mathrm{C}$, respectively. The soil type of the area is Nitosol which is dark reddish brown to dark red in color and the crops mainly cultivated in the area are sorghum, maize, soybean and finger millet [20]. The laboratory experiment was conducted at Haramaya University in school of plant sciences seed science and plant pathology laboratory.

\subsection{Treatments and Experimental Design}

The treatments consist of three varieties of soybean namely Belessa- 95, Wello and Gishama and priming treatments $\mathrm{GA}_{3}(100 \mathrm{PPM}), \mathrm{KH}_{2} \mathrm{PO}_{4}(50 \mathrm{PPM})$ and water at timings of 0,6 and $12 \mathrm{hr}$. The size of each plot was $4 \times 3 \mathrm{~m}$ $\left(12 \mathrm{~m}^{2}\right)$. The space between blocks was $1 \mathrm{~m}$, the space between rows in each plot was $60 \mathrm{~cm}$ and spacing between plants was $5 \mathrm{~cm}$. The rate of fertilizer used was $100 \mathrm{~kg}$ DAP which contains $18 \% \mathrm{~N}$ and $46 \% \mathrm{P}_{2} \mathrm{O}_{5}$ as a source of Nitrogen and Phosphorus. The experiment was laid out in factorial arrangement using Randomized Complete Block Design (RCBD) (for field experiment). Soybean varieties were harvested and tested for laboratory quality by using Completely Randomized Design (CRD) in three replications.

Table 1. Description of the soybean varieties used for the study.

\begin{tabular}{|c|c|c|c|c|c|}
\hline No & Soybean varieties & Maturity period (days) & Seed size & Seed shape & Seed colour \\
\hline 1 & Belessa- 95 & 135 & Medium size & Round & Yellowish \\
\hline 2 & Gishama & 97 & Medium size & Flat oval & Light yellowish \\
\hline 3 & Wello & 121 & Medium size & Oval & Yellowish \\
\hline
\end{tabular}

\subsection{Experimental Procedure and Field Management}

The land was prepared for planting by tractor, disked and harrowed. The seeds of all the three varieties were soaked in $\mathrm{GA}_{3}$ (100 PPM), $\mathrm{KH}_{2} \mathrm{PO}_{4}$ (50 PPM) and water for 0,6 and 12 hours. The seeds of all the varieties were used as control where Hydro priming and osmopriming treatments were not applied. After giving treatment for 0,6 and 12 hours the seed was removed from water and solutions then it was kept in filter paper to remove the remaining solution. All the primed seeds were again re-dried at room temperature until they gain their original seed moisture content. Seed was sown in last week of June 2015 in rows by placing the seeds at an appropriate distance as per the treatments with the help of tape meter and then covered it manually with the soil. All cultural practices such as weeding fertilizer application etc were applied uniformly to all plants. The crop was harvested manually when the crop reached physiological maturity and sun dried for up to 14 days to adjust the moisture contents of the seed to $10 \%$ and converted to yield per hectare after adjusting to $10 \%$ moisture content. Then seed quality analysis was tested at laboratory.

\subsection{Laboratory Analysis}

Seed quality analysis: Soybean seed obtained from experimental plots were harvested and seed quality was determined. The experiment was conducted in a Complete Randomized Design (CRD) with four replications as per [21] procedure.

\subsubsection{Determination of Physical Quality}

The $1000 \mathrm{~g}$ submitted sample was taken from each treatment. The submitted samples were divided in to two and one of the sub divided portions was partitioned in two replication for purity, standard germination and vigor tests. The working sample was separated into pure seed, other crop seed, weed seed and inert matter by keeping on Purity work board with the help of spatula [22]. The purity and other purity components were determined in percentage by using "(1)"

$$
\left[\text { Purity }(\%)=\frac{\text { Weightofpureseed }(g)}{\text { Totalweightofworkingsample }} \times 100\right.
$$

\subsubsection{Physiological Quality Test}

i. Standard germination test

Standard germination test was done from each soybean seed varieties of primed and unprimed seed using Complete Randomized Design. Four hundred (400) seeds were randomly taken from mixed pure seed component of purity test and divided in to four replicates of 100 seeds each. The seeds were sown in sterilized sand medium and kept in Seed germinator at $25^{\circ} \mathrm{C}$ temperature. The first count was done on $5^{\text {th }}$ day after planting and final count was done on $8^{\text {th }}$ day. Seedling was evaluated in to normal, abnormal. Seedling, Hard and dead seed. The standard germination was calculated in percentage [21] as follow:

$\left[\right.$ Germination $(\%)=\frac{\text { Totalnumberofnormalseeedling }}{\text { Totalnumberofseedsplanted }} X 100$

ii. Moisture content determination

Seed moisture content was determined by air oven method. This was carried out in two replications independently drawn $10 \mathrm{~g}$ working samples from each treatment, which was weighed with an electronic balance. The samples were dried at $103^{\circ} \mathrm{C}$ for 17 hours. The seed samples were kept in the oven for drying when it reached the required temperature. At the end of drying period, the container was transferred in to 
the desiccators, the desiccators were closed and the sample allowed for cooling. It was then weighed again and the moisture content was calculated by the following formula "(3)"

$$
\left[M C=\frac{(\mathrm{M} 2-\mathrm{M} 3)}{(\mathrm{M} 2-\mathrm{M} 1)} x 100 \%\right.
$$

Where $\mathrm{M}=$ seed moisture content

$\mathrm{M}_{1}=$ weight of the empty container with its lid.

$\mathrm{M}_{2}=$ weight of the container with its cover and seed before drying

$\mathrm{M}_{3}=$ Weight of the container with its cover and seeds after drying.

iii. Seed vigor test

a) Shoot and root length of seedlings

Shoot and root lengths were determined by measuring average number of shoot and root length in centimeter. After completion of germination period eight days in randomly selected ten normal seedlings from each treatment and replications. The shoot length of the seedlings was measured from the point of attachment to the embryo to the tip of the root. The averages of shoot and root length was computed by dividing the total shoot or root lengths by the total number of normal seedlings on which measurement was done [23].

b) Seedlings dry weight

Seedling dry weight was determined by obtaining a sample of randomly selected ten normal seedlings after germination in laboratory and the seedling was placed in paper bags, dried at $80^{\circ} \mathrm{C}$ for 24 hours, and weighed [24]. The seedlings were dried and weighed to the nearest milligram and the average seedling dry weight was calculated.

c) Vigor index- 1 and vigor index- 2

Seedling vigor index 1 was calculated by multiplying the standard germination with the average sum of shoot length and root length after 8 days of germination and vigor index 2 was again calculated by multiplying the standard germination with mean seedling dry weight (drying at temperature of $80^{\circ} \mathrm{C}$ for 24 hours) [25]. The formula for these parameters is "(4)" and "(5)" respectively.

$$
\text { [SVI } 1 \text { = Standard germination } \times \text { mean seedling length (roots }+ \text { shoot length })
$$

$$
\text { [SVI } 1 \text { = Standard germination } \times \text { mean seedling dry weight }
$$

d) Speed of germination (SG)

Speed of germination is also another indicator used for assessing the vigor of seeds. One hundred seeds were taken from each sample and divided into four replicates and kept at $25^{\circ} \mathrm{C}$ temperature for maximum of 8 days in the seed germinator. Germination was evaluated as the percentage of seeds producing normal seedlings as defined by [26]. Normal seedlings were counted and tagged at each day. Then, speed of germination (GS) was calculated [27] as follows:

$$
\left[S G=\frac{\text { Number of Normal Seedlings }+\cdots+\text { Number of Normal Seedlings }}{\text { Days of First Count Days of Final Count }}\right.
$$

\section{e) Electrical Conductivity test}

Two hundred seeds were taken from each treatment and fifty seeds per replication were used. The sample from each treatment was weighted and the seed was soaked in $100 \mathrm{ml}$ distilled water in $150 \mathrm{ml}$ flask overnight and covered the flask and kept at $20^{\circ} \mathrm{C}$. In one beaker seeds were not added and only $100 \mathrm{ml}$ distilled water was added and was used as check or control. The conductivity of distilled water was measured with conductivity meter and was expressed in $\mu \mathrm{Scm}^{-1} \mathrm{~g} .^{-1}$

f) Field Emergence index

All treatments were sown in a pot experiment using well prepared soil for emergence. $4 \times 100$ seeds were planted from each variety. The emergence data were recorded daily until further emergence stopped. The field emergence index was calculated by dividing the number of seedlings emerged at each day with the number of days in which they were emerged [28]. The formula is "(7)"

$$
\left[E I=\frac{\text { Number of Seedlings Emerged }}{\text { Days of First Count }}+\ldots+\frac{\text { Number of Seedling Emerged at FinalCount }}{\text { Days of Final Count }}\right.
$$

\subsubsection{Seed Health Testing}

Seed sample were studied for association of different fungal and bacterial seed- borne pathogen. The procedure for Isolation of seed borne bacteria and fungi was similar whereas the identification was different. Seed borne pathogens were tested by using agar plate method (for internal pathogens). The Seeds were treated with $1 \%$ sodium hypochlorite $(\mathrm{NaOCl})$ solution for five minutes. Ten seeds were placed at equal distance on Petri-dishes which replicate four times and then incubated at a temperature of $25^{\circ} \mathrm{C}$ with alternating light and dark period of 12 hours for eight days and then slides were prepared in order to identify. Identification for seed borne fungi was based on morphological traits including colony features, structures, and spores using stereo- and compound-microscopes. Identification for bacterial seed borne disease was based on Bacterial colonies grows from a single cell and is composed of millions of cells. Each colony has a characteristic size, form or shape, edge, texture, degree of opacity, and color. These characteristics describe the morphology of a single colony and may be useful in the preliminary identification of a bacterial species. In addition to cell morphology; the specific arrangement of cells is an important identifying characteristic of many bacteria. Bacterial cells are found singly, in pairs, in clusters, or in chains when viewed under the microscope. In addition to morphologies of the cell and of the colony, other morphological characteristics can be useful in initial identifications. Percentage of seed infection by each pathogen was calculated as: 
$\left[\right.$ Seed infection $(\%)=\frac{\text { Number of infected seed }}{\text { Total number of seed }} \times 100 \%$

\subsection{Data Analysis}

Data were subjected to Analysis of Variance (ANOVA) with computer software SAS statistical package, Version 9.1 (SAS, 2000) [29]. Whenever the effects of the factors were found to be significant, the means were compared using the Tukey's Studentized Range (HSD) test at 5\% level of significance.

\section{Results and Discussions}

\subsection{Determination of Physical Quality}

The purity and other purity components were determined in percent. The highest pure seeds in percent were observed for Gishema variety primed with $\mathrm{GA}_{3}$ for $12 \mathrm{hr}$ (99.60) followed by Gishema variety primed with $\mathrm{GA}_{3}$ for $6 \mathrm{hr}(99.20)$ and $0 \mathrm{hr}$ (99.04) which is at par with Belessa95 variety primed with $\mathrm{KH}_{2} \mathrm{PO}_{4}$ for $0 \mathrm{hr}$ (98.96), Wello variety primed with $\mathrm{KH}_{2} \mathrm{PO}_{4}$ for $12 \mathrm{hr}(98.96)$ and Gishema variety primed with $\mathrm{KH}_{2} \mathrm{PO}_{4}$ for Ohr (98.92) whereas the other shows intermediate values. The lowest pure seeds in percent were observed for Belessa95 variety primed with water for $0 \mathrm{hr}$ (96.72) followed by Wello variety primed with $\mathrm{GA}_{3}$ for $6 \mathrm{hr}$ (97.16) and $12 \mathrm{hr}$ (97.16) which was at par with unprimed Belessa95 variety (97.40) and Belessa95 variety primed with water for $6 \mathrm{hr}$ (97.72) (Table 2). The lowest inert matter in percent were observed for Gishema variety primed with $\mathrm{GA}_{3}$ for $12 \mathrm{hr}(0.40)$ followed by Gishema variety primed with $\mathrm{GA}_{3}$ for $6 \mathrm{hr}(0.80)$ and $0 \mathrm{hr}(0.96)$ followed by unprimed Wello variety (1.00), Wello variety primed with $\mathrm{KH}_{2} \mathrm{PO}_{4}$ for $12 \mathrm{hr}$ (1.04) and Gishema variety primed with $\mathrm{KH}_{2} \mathrm{PO}_{4}$ for $0 \mathrm{hr}$ (1.08). The highest inert matter in percent were observed for Gishema variety primed with water for $6 \mathrm{hr}$ (2.04), Wello variety primed with $\mathrm{GA}_{3}$ for $6 \mathrm{hr}$ (2.04) and Gishema variety primed with water for $12 \mathrm{hr}(2.00)$. Zero percent was observed for weed seed and other crop seeds on all of the treatments whereas the other shows intermediate values (Table 2).

Table 2. Percentages composition of pure seeds, inert matter, weed seeds and other crop seeds for three different soybean varieties primed for different soaking durations.

\begin{tabular}{|c|c|c|c|c|c|c|}
\hline & & & $\% \mathrm{PS}$ & $\%$ IM & $\% \mathrm{WS}$ & $\% \mathrm{OCS}$ \\
\hline Variety & PT & Timing & & & & \\
\hline Belessa95 & Unprimed & Control & 97.40 & 1.80 & Trace & Trace \\
\hline Belessa95 & $\mathrm{GA}_{3}$ & 0 & 98.44 & 1.56 & Trace & Trace \\
\hline Belessa95 & $\mathrm{GA}_{3}$ & 6 & 98.04 & 1.96 & Trace & Trace \\
\hline Belessa95 & $\mathrm{GA}_{3}$ & 12 & 98.40 & 1.60 & Trace & Trace \\
\hline Belessa95 & $\mathrm{KH}_{2} \mathrm{PO}_{4}$ & 0 & 98.96 & 1.44 & Trace & Trace \\
\hline Belessa95 & $\mathrm{KH}_{2} \mathrm{PO}_{4}$ & 6 & 98.80 & 1.20 & Trace & Trace \\
\hline Belessa95 & $\mathrm{KH}_{2} \mathrm{PO}_{4}$ & 12 & 98.08 & 1.48 & Trace & Trace \\
\hline Belessa95 & Water & 0 & 96.72 & 1.68 & Trace & Trace \\
\hline Belessa95 & Water & 6 & 97.72 & 1.48 & Trace & Trace \\
\hline Belessa95 & Water & 12 & 98.04 & 1.16 & Trace & Trace \\
\hline Wello & Unprimed & Control & 98.08 & 1.00 & Trace & Trace \\
\hline Wello & $\mathrm{GA}_{3}$ & 0 & 98.24 & 1.76 & Trace & Trace \\
\hline
\end{tabular}

\begin{tabular}{|c|c|c|c|c|c|c|}
\hline & & & $\% \mathrm{PS}$ & $\%$ IM & $\% W S$ & $\% \mathrm{OCS}$ \\
\hline Wello & $\mathrm{GA}_{3}$ & 6 & 97.16 & 2.04 & Trace & Trace \\
\hline Wello & $\mathrm{GA}_{3}$ & 12 & 97.16 & 1.64 & Trace & Trace \\
\hline Wello & $\mathrm{KH}_{2} \mathrm{PO}_{4}$ & 0 & 98.48 & 1.52 & Trace & Trace \\
\hline Wello & $\mathrm{KH}_{2} \mathrm{PO}_{4}$ & 6 & 98.56 & 1.44 & Trace & Trace \\
\hline Wello & $\mathrm{KH}_{2} \mathrm{PO}_{4}$ & 12 & 98.96 & 1.04 & Trace & Trace \\
\hline Wello & Water & 0 & 98.76 & 1.24 & Trace & Trace \\
\hline Wello & Water & 6 & 98.40 & 1.60 & Trace & Trace \\
\hline Wello & Water & 12 & 98.56 & 1.44 & Trace & Trace \\
\hline Gishema & Unprimed & Control & 98.80 & 1.20 & Trace & Trace \\
\hline Gishema & $\mathrm{GA}_{3}$ & 0 & 99.04 & 0.96 & Trace & Trace \\
\hline Gishema & $\mathrm{GA}_{3}$ & 6 & 99.20 & 0.80 & Trace & Trace \\
\hline Gishema & $\mathrm{GA}_{3}$ & 12 & 99.60 & 0.40 & Trace & Trace \\
\hline Gishema & $\mathrm{KH}_{2} \mathrm{PO}_{4}$ & 0 & 98.92 & 1.08 & Trace & Trace \\
\hline Gishema & $\mathrm{KH}_{2} \mathrm{PO}_{4}$ & 6 & 98.76 & 1.24 & Trace & Trace \\
\hline Gishema & $\mathrm{KH}_{2} \mathrm{PO}_{4}$ & 12 & 98.80 & 1.20 & Trace & Trace \\
\hline Gishema & Water & 0 & 98.40 & 1.60 & Trace & Trace \\
\hline Gishema & Water & 6 & 97.96 & 2.04 & Trace & Trace \\
\hline Gishema & Water & 12 & 98.00 & 2.00 & Trace & Trace \\
\hline
\end{tabular}

Where, $\mathrm{PT}=$ Priming types, $\% \mathrm{PS}=$ Percent of pure seed,\%IM=percent of inert matter, $\% \mathrm{WS}=$ percent of weed seed, $\% \mathrm{OCS}=$ percent of other crop seeds and $\mathrm{GA}_{3}=$ Gibberallic acid, $\mathrm{KH}_{2} \mathrm{PO}_{4}=$ Potassium dihydrophosphate.

\subsection{Physiological Seed Quality Test}

i. Standard germination test

There was a highly significant $(\mathrm{P} \leq 0.01)$ difference among priming type and significance $(\mathrm{P} \leq 0.05)$ difference among varieties in standard germination percentage. Comparing the varieties the highest standard germination was recorded on variety Belessa $95(91.27 \%)$ and the lowest on variety Gishema (89.80\%) which is statistically not different from variety Wello (90\%) (Table 3). The variations among variety might be due to genetic difference. Seed primed with water (92.67) effectively improved the germination percentage of varieties followed by $\mathrm{KH}_{2} \mathrm{PO}_{4}$ (89.85) which is at par with seed primed with $\mathrm{GA}_{3}$ (89.41). The result agreed with that of the report seed primed with water effectively improved the germination percentage of chickpea varieties [30]. The higher germination percentage in case of primed seed might be due to break down of dormancy and removal of germination inhibitors. Hydropriming affects DNA and RNA synthesis, ATP availability, alpha-amylase activity and embryo's better growth. Hence, germination with better rate, growth consistency, seeding vigor and development leads to better plant growth [31] and [32]. Similar result was also studied which suggested that under normal conditions hydro priming is effective for germination and later growth of chickpea [32]. On the other hand, chickpea seed primed with $\mathrm{GA}_{3}$ recorded the highest (91.67) germination percentage [33]. Also another report indicated that use of $\mathrm{GA}_{3}$ in germination of soybean seeds, suggesting that gibberellic acid would play an important role during the germination process of seeds [34]. According to research observed phosphorous reserves in the seed play very important role in the metabolism of germinating seed. The major phosphorous reserve in the seed, phytic acid, in addition to its nutritional role, is believed to act as a natural antioxidant [35]. 
Table 3. Main effect of priming types and Soybean varieties on standard germination test and Root length.

\begin{tabular}{lll}
\hline Variety & SG & RL \\
\hline Belessa & $91.27^{\mathrm{A}}$ & $6.98^{\mathrm{A}}$ \\
Wello & $90.00^{\mathrm{B}}$ & $6.77^{\mathrm{B}}$ \\
Gishema & $89.80^{\mathrm{B}}$ & $6.70^{\mathrm{B}}$ \\
LSD $(0.05)$ & 0.53 & 0.16 \\
Priming type & & \\
Water & $92.67^{\mathrm{A}}$ & $7.22^{\mathrm{A}}$ \\
$\mathrm{KH}_{2} \mathrm{PO}_{4}$ & $89.85^{\mathrm{B}}$ & $7.12^{\mathrm{A}}$ \\
$\mathrm{GA}$ & $89.41^{\mathrm{B}}$ & $6.21^{\mathrm{B}}$ \\
$\mathrm{LSD}(0.05)$ & 0.94 & 0.19 \\
$\mathrm{CV}(\%)$ & 0.80 & 5.25 \\
\hline
\end{tabular}

Where, $\mathrm{SG}=$ Standard Germination, $\mathrm{RL}=$ Root Length, $\mathrm{GA}_{3}=$ Gibberellic acid, $\mathrm{KH}_{2} \mathrm{PO}_{4}=$ Potassium dihydrophosphate. Means followed by the same letter at each column are not significantly different from each other at 0.05 level of probability.

\section{ii. Moisture Content}

There was highly significance differences $(\mathrm{P} \leq 0.01)$ between varieties. Comparing the varieties the highest moisture contents was recorded on variety Gishema (12.37) and the lowest moisture contents was recorded on Wello (11.97) followed by Belessa95 (11.53) varieties (Table 4). The variation among varieties to moisture contents might be due to genetic differences.

Table 4. Main effect Soybean varieties on moisture content.

\begin{tabular}{llll}
\hline Variety & Gishema & Wello & Belessa \\
\hline Moisture content & $12.37^{\mathrm{A}}$ & $11.97^{\mathrm{B}}$ & $11.53^{\mathrm{C}}$ \\
LSD & 0.18 & & \\
CV $(\%)$ & 2.7 & & \\
\hline
\end{tabular}

Means followed by the same letter at row are not significantly different from each other at 0.05 level of probability.

\subsection{Seed Vigor}

\section{i. Shoot Length}

There was a highly significant $(\mathrm{P} \leq 0.01)$ difference among varieties, seed priming type, and their interaction effect and Significant differences $(\mathrm{P} \leq 0.05)$ among priming duration for Root length. The highest shoot length was recorded when variety Belessa95 was primed with $\mathrm{GA}_{3}(16.31)$ followed by Wello variety primed with $\mathrm{GA}_{3}(15.54 \mathrm{~cm})$ which is at par with that of Gishema variety primed with $\mathrm{KH}_{2} \mathrm{PO}_{4}(15.41 \mathrm{~cm})$ and Gishema variety primed with $\mathrm{GA}_{3}(15.14 \mathrm{~cm})$ (Table 5). This finding is in agreement with the report which described that highest shoot length $(27.03 \mathrm{~cm})$ was achieved when mung bean seed is primed with $\mathrm{KH}_{2} \mathrm{PO}_{4} @ 200 \mathrm{mM}$ and there was an increase of $52 \%$ in shoot length observed in seed primed with $\mathrm{KH}_{2} \mathrm{PO}_{4} @ 200 \mathrm{mM}$ as compared to control [36]. The lowest shoot length was observed on unprimed Belessa95 variety (11.39) followed by Wello variety (12.77) and Gishema variety (12.88). This finding is also in agreement with the report which described that chickpea seed primed with $\mathrm{KH}_{2} \mathrm{PO}_{4}(0.5 \%)$ enhanced shoot length by $14 \%$ compared to unprimed chickpea varieties [30]. Similarly, another report was also suggested that priming mung bean (Vigna radiata L.) with water and $\mathrm{KH}_{2} \mathrm{PO}_{4} \mathrm{KH}_{2} \mathrm{PO}_{4} @ 200$ $\mathrm{mM}$ improves the growth of shoot length [36].
Table 5. Interaction effects of Soybean varieties and priming types on shoot Length.

\begin{tabular}{ll}
\hline Interaction & Shoot Length \\
\hline Belessa95 $\times$ Unprimed (Control) & $11.39^{\mathrm{g}}$ \\
Belessa95 $\times$ Gibberellic acid & $16.31^{\mathrm{a}}$ \\
Belessa95 $\times$ Potassium dihydrophosphate & $14.14^{\mathrm{de}}$ \\
Belessa95 $\times$ Water & $14.04^{\mathrm{cd}}$ \\
Wello $\times$ Unprimed (Control) & $12.77^{\mathrm{f}}$ \\
Wello $\times$ Gibberellic acid & $15.52^{\mathrm{b}}$ \\
Wello $\times$ Potassium dihydrophosphate & $14.10^{\mathrm{de}}$ \\
Wello $\times$ Water & $13.73^{\mathrm{e}}$ \\
Gishema $\times$ Unprimed (Control) & $12.88^{\mathrm{f}}$ \\
Gishema $\times$ Gibberellic acid & $15.14^{\mathrm{bc}}$ \\
Gishema $\times$ Potassium dihydrophosphate & $15.41^{\mathrm{bc}}$ \\
Gishema $\times$ Water & $15.19^{\mathrm{bc}}$ \\
LSD & 0.78 \\
CV & 3.23 \\
\hline
\end{tabular}

Means followed by the same letter (s) at column are not significantly different from each other at 0.05 level of probability.

\section{ii. Root Length}

There was a highly significant $(\mathrm{P} \leq 0.01)$ difference among priming type and significance $(\mathrm{P} \leq 0.05)$ difference among varieties in enhancing root length. Comparing the varieties the highest root length was recorded on variety Belessa 95 $(6.98 \mathrm{~cm})$ followed by Wello variety $(6.77 \mathrm{~cm})$ which is statically at par with Gishema variety $(6.70 \mathrm{~cm})$ (Table 3$)$. Comparing priming treatments the highest root length was recorded when the varieties was primed with water $(7.22 \mathrm{~cm}$.) which is on par with seed primed with $\mathrm{KH}_{2} \mathrm{PO}_{4}(7.12 \mathrm{~cm})$ where as seed primed with $\mathrm{GA}_{3}(6.21 \mathrm{~cm})$ showed intermediate value (Table 3 ). This result were consistent with the finding which reported that soybean seed primed with $\mathrm{GA}_{3}$ records $(18.55 \mathrm{~cm})$ of Root length followed by $\mathrm{KH}_{2} \mathrm{PO}_{4}$ $(18.53 \mathrm{~cm})$ and water $(18.40 \mathrm{~cm})$ [37]. Similar report improved that chickpea seed primed with $\mathrm{KH}_{2} \mathrm{PO}_{4}(0.5 \%)$ enhanced root length by $14 \%$ compared to unprimed chickpea varieties [30]. Another report also suggested that priming mung bean (Vigna radiate L.) with water and $\mathrm{KH}_{2} \mathrm{PO}_{4} @ 200 \mathrm{mM}$ improves the growth of root length under laboratory conditions [36].

According to previous study an increased weight of primed seed lots and increase in root length was due to activation of cell respiration, repairs of macromolecules, movements of acquired materials, activation of cell cycling, the result of higher embryo-cell wall extensibility and weakening of seed coat structure for radical emergence [38]. The increased shoot and root length with osmoprimg treatments might be due to increased nuclear replications in shoot and roots.

iii. Seedling dry weight

There was highly significance difference $(\mathrm{P} \leq 0.01)$ among varieties, priming type, and their interaction effect on Seedling dry weight. The highest seedling dry weight was recorded when Belessa95 variety primed with water for $12 \mathrm{hr}$ $(250 \mathrm{gm})$, and Gishema variety primed with water for $6 \mathrm{hr}$ (250gm) which is at par with Wello variety primed with $\mathrm{KH}_{2} \mathrm{PO}_{4}$ for $0 \mathrm{hr}(246.67 \mathrm{mg})$, Gishema variety primed with water for $12 \mathrm{hr}(243.33 \mathrm{mg})$, for $0 \mathrm{hr}(240 \mathrm{mg})$ and Belessa95 variety primed with water for $6 \mathrm{hr}(240 \mathrm{gm})$, with $\mathrm{GA}_{3}$ for 12 
$\mathrm{hr}$ (240mg). The lowest seedling dry weight was recorded for un primed Gishema variety $(166.67 \mathrm{gm})$ and Belessa95 variety primed with $\mathrm{KH}_{2} \mathrm{PO}_{4}$ for $6 \mathrm{hr}(166.67 \mathrm{mg})$ which is at par with Gishema and Wello variety primed with $\mathrm{KH}_{2} \mathrm{PO}_{4}$ for $12 \mathrm{hr}(170 \mathrm{mg})$. whereas the other showed intermediate values. Three of unprimed soybean varieties record the lower seedling dry weight compared to primed soybean varieties (Table 6).

The results of the present study revealed that priming has an effect in enhancing seedling dry weight. This is in agreement with previous findings which reported that chickpea seed primed with $\mathrm{KH}_{2} \mathrm{PO}_{4}(0.5 \%)$ and water records an increments in seedling dry weight $(0.066 \mathrm{~g})$ and $(0.062 \mathrm{~g})$ respectively compared to the unprimed chickpea variety which records $(0.056 \mathrm{~g})$ [30]. Another report also suggested that priming mung bean (Vigna radiata L.) with water and $\mathrm{KH}_{2} \mathrm{PO}_{4}(0.6 \%)$ for five hours improve the growth of shoot, root length and seedling dry weight under laboratory conditions [39]. The results of the present study also in agreement with the report which described that primed soybean seed increases seedling dry weight by $(58.1 \%)$ compared to the unprimed one [40]. Similar finding also described that priming improved seedling dry weight under laboratory and field conditions [41].

Table 6. Interaction effects of priming type durations and varieties on seedling dry weight.

\begin{tabular}{|c|c|c|c|c|}
\hline \multirow{2}{*}{ Variety } & \multirow{2}{*}{ PT } & \multicolumn{3}{|c|}{ Priming durations } \\
\hline & & $\mathbf{0}$ & 6 & 12 \\
\hline \multirow[t]{4}{*}{ Belessa 95} & $\mathrm{GA}_{3}$ & $230.00^{\text {abcd }}$ & $236.67^{\mathrm{abc}}$ & $240.00^{\mathrm{abc}}$ \\
\hline & $\mathrm{KH}_{2} \mathrm{PO}_{4}$ & $230.00^{\mathrm{abcd}}$ & $166.67^{f}$ & $196.67^{\text {cdef }}$ \\
\hline & Water & $233.33^{\mathrm{abcd}}$ & $240.00^{\mathrm{abc}}$ & $250.00^{\mathrm{a}}$ \\
\hline & Control & $206.67^{\text {abcdef }}$ & $206.67^{\text {abcdef }}$ & $206.67^{\text {abcdef }}$ \\
\hline \multirow[t]{4}{*}{ Wello } & $\mathrm{GA}_{3}$ & $233.33^{\mathrm{abcd}}$ & $233.33^{\mathrm{abcd}}$ & $230.00^{\mathrm{abcd}}$ \\
\hline & $\mathrm{KH}_{2} \mathrm{PO}_{4}$ & $246.67^{\mathrm{ab}}$ & $176.67^{\mathrm{ef}}$ & $170.00^{f}$ \\
\hline & Water & $210.00^{\text {abcdef }}$ & $233.33^{\mathrm{abcd}}$ & $233.33^{\mathrm{abcd}}$ \\
\hline & Control & $213.33^{\mathrm{abcdf}}$ & $213.33^{\mathrm{abcdf}}$ & $213.33^{\mathrm{abcdf}}$ \\
\hline \multirow[t]{4}{*}{ Gishema } & $\mathrm{GA}_{3}$ & $176.67^{\mathrm{ef}}$ & $223.33^{\text {abcde }}$ & $240.00^{\mathrm{abc}}$ \\
\hline & $\mathrm{KH}_{2} \mathrm{PO}_{4}$ & $200.00^{\text {bcdef }}$ & $186.67^{\mathrm{def}}$ & $170.00^{\mathrm{f}}$ \\
\hline & Water & $240.00^{\mathrm{abc}}$ & $250.00^{\mathrm{a}}$ & $243.33^{\mathrm{abc}}$ \\
\hline & Control & $166.67^{f}$ & $166.67^{f}$ & $166.67^{\mathrm{f}}$ \\
\hline LSD & & & & 47.19 \\
\hline $\mathrm{CV}$ & & & & 6.76 \\
\hline
\end{tabular}

Where, $\mathrm{PT}=$ Priming type $\mathrm{GA}_{3}=$ Gibberellic acid, $\mathrm{KH}_{2} \mathrm{PO}_{4}=$ Potassium dihydrophosphate. Means followed by the same letter (s) at each column and row are not significantly different from each other at 0.05 level of probability.

\section{iv. Seedling Vigor index 1 (SVI-1)}

The analysis of variance showed that there was highly significance difference $(\mathrm{P} \leq 0.01)$ among varieties, priming type, duration of priming and significance difference $(\mathrm{P} \leq 0.05)$ for their interaction effects on Seedling vigor index 1. Primed variety showed an increase seedling vigor index 1 over the control. The highest seedling vigor index1 (SVI-1) was recorded when Gishema variety primed with $\mathrm{KH}_{2} \mathrm{PO}_{4}$ for $6 \mathrm{hr}$ (2202.20) which is at par with Gishema variety primed with water for $12 \mathrm{hr}$ (2152.33) and Belessa95 variety primed with $\mathrm{KH}_{2} \mathrm{PO}_{4}$ for $0 \mathrm{hr}$ (2126.13) followed by Wello variety primed with $\mathrm{KH}_{2} \mathrm{PO}_{4}$ for $0 \mathrm{hr}$ (2114.84) and with water for $12 \mathrm{hr}$ (2096.07) whereas the other combination shows an intermediate values. The lowest SVI-1 showed on unprimed Belessa95 variety (1516.83) followed by Belessa95 variety primed with $\mathrm{GA}_{3}$ for $0 \mathrm{hr}$ (1586.67) and for 6hr (1628.33) which is at par with Gishema variety primed with water for Ohr (1721.28)(Table7).

This is supported by the previous findings which reported that both hydro priming and osmopriming $0.6 \% \mathrm{KH}_{2} \mathrm{PO}_{4}$ improved seedling vigor index 1 of mung bean (Vigna radiatea L.) [39]. Similarly, $\mathrm{P}$ enrichment by soaking seeds

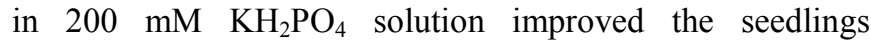
establishment [42]. The increased vigor of P-enriched seed might be due to increased $P$ content both inside the seeds and on the seed surfaces which leads to better establishment of seedlings [43, 44, 45] and [46]. Similarly, the increase in seedling vigor due to salicylic acid may be due to enhanced oxygen uptake and the efficiency of mobilizing nutrients from the cotyledons to the embryonic axis and decreased catalase and peroxidase levels as recorded in pea seedlings [47] and [48].

Table 7. Interaction effects of priming types, duration and varieties on seedling vigor index 1 .

\begin{tabular}{|c|c|c|c|c|}
\hline \multirow{2}{*}{ Variety } & \multirow{2}{*}{ PT } & \multicolumn{3}{|c|}{ Priming durations } \\
\hline & & $\mathbf{0}$ & 6 & 12 \\
\hline \multirow[t]{4}{*}{$\begin{array}{l}\text { Belessa } \\
95\end{array}$} & $\mathrm{GA}_{3}$ & $1586.67^{\mathrm{ij}}$ & $1628.33^{\text {ghij }}$ & $1888.56^{\text {cdefgh }}$ \\
\hline & $\mathrm{KH}_{2} \mathrm{PO}_{4}$ & $2126.13^{\mathrm{abc}}$ & $1933.95^{\text {bcdefg }}$ & $1819.69^{\text {fghi }}$ \\
\hline & Water & $1978.55^{\text {abcdefg }}$ & $1959.00^{\text {abcdefg }}$ & $1926.36^{\text {bcdefg }}$ \\
\hline & Control & $1516.83^{\mathrm{j}}$ & $1516.83^{\mathrm{j}}$ & $1516.83^{\mathrm{j}}$ \\
\hline \multirow[t]{4}{*}{ Gishema } & $\mathrm{GA}_{3}$ & $1815.11^{\text {fghi }}$ & $1928.63^{\text {bcdefg }}$ & $1959.59^{\text {abcdefg }}$ \\
\hline & $\mathrm{KH}_{2} \mathrm{PO}_{4}$ & $2053.32^{\text {abcdef }}$ & $2202.20^{\mathrm{a}}$ & $1922.91^{\text {efghi }}$ \\
\hline & Water & $1721.28^{\text {ghij }}$ & $1901.77^{\text {fghi }}$ & $2152.33^{\mathrm{ab}}$ \\
\hline & Control & $1828.99^{\text {efghi }}$ & $1828.99^{\text {efghi }}$ & $1828.99^{\text {efghi }}$ \\
\hline \multirow[t]{4}{*}{ Wello } & $\mathrm{GA}_{3}$ & $1813.89^{\text {fghi }}$ & $1928.63^{\text {efghi }}$ & $2084.59^{\text {abcde }}$ \\
\hline & $\mathrm{KH}_{2} \mathrm{PO}_{4}$ & $2114.84^{\text {abcd }}$ & $1857.27^{\text {defgh }}$ & $1922.91^{\text {bcdefg }}$ \\
\hline & Water & $1903.40^{\text {bcdefg }}$ & $1901.77^{\text {bcdefg }}$ & $2096.07^{\mathrm{abcd}}$ \\
\hline & Control & $2031.87^{\text {abcdef }}$ & $2031.87^{\text {abcdef }}$ & $2031.87^{\text {abcdef }}$ \\
\hline LSD & & & & 263.52 \\
\hline $\mathrm{CV}$ & & & & 4.25 \\
\hline
\end{tabular}

Where, $\mathrm{PT}=$ Priming types $\mathrm{GA}_{3}=$ Gibberellic acid, $\mathrm{KH}_{2} \mathrm{PO}_{4}=$ Potassium dihydrophosphate. Means followed by the same letter (s) at each column and row are not significantly different from each other at 0.05 level of probability.

\section{v. Seedling Vigor index 2 (SVI 2)}

There was highly significance difference $(\mathrm{P} \leq 0.01)$ among varieties, priming type and between their interaction effects for increments of Seedling vigor index 2. Primed variety showed an increased seedling vigor index 2 (SVI-2) over the control. The highest seedling vigor index 2 was recorded when Belessa95 variety primed with water for $12 \mathrm{hr}$ (23673), for $6 \mathrm{hr}$ (23027), followed by Gishema variety primed with water for $6 \mathrm{hr}$ (22833), Wello variety primed with water for $6 \mathrm{hr}$ (22087) and Gishema variety primed with water for $0 \mathrm{hr}$ (22073) and the other combination shows an intermediate values Whereas the lowest SVI-2 was recorded on unprimed Gishema variety (14140) followed by Belessa95 variety primed withGA $\mathrm{A}_{3}$ for $6 \mathrm{hr}$ (15153), Wello variety primed with $\mathrm{KH}_{2} \mathrm{PO}_{4}$ for $12 \mathrm{hr}(15273)$ and Gishema variety primed with $\mathrm{GA}_{3}$ for $0 \mathrm{hr}$ (15633). This parameter depends on germination percentage and seedling dry weight. However, the present 
study showed that priming treatments showed an increment in germination percentages and seedling dry weight which increases SVI-2. In three of the varieties unprimed varieties records a lower SVI-2 compared to the primed varieties (Table 8). This finding was in agreement with the previous finding which reported that soybean seed primed with $\mathrm{CaCl}_{2} .2 \mathrm{H}_{2} \mathrm{O}, \mathrm{GA}_{3}, \mathrm{KH}_{2} \mathrm{PO}_{4}$, and hydro- primed seeds recorded $(21.70,24.70 \%),(17.78,22.62 \%)(11.90,10.75 \%)$ and $(13.80,9.05 \%)$ increments in seedling dry weight and vigor index when judged against the control respectively [49]. Another report improved that chickpea variety primed with $0.5 \% \mathrm{KH}_{2} \mathrm{PO}_{4}$ and water resulted in $21 \%$ and $15 \%$ increase in seedling vigor index 2 respectively as compared to the control [30]. Similar finding concluded that seedling dry weight represents a logical and relevant estimate of seed vigor, What is more seedling dry weight was affected by shoot and root length of the seedling, So increased shoot and root length due to water and osomopriming in turn could enhance vigor index $2[50]$.

Table 8. Interaction effects of priming types, duration and varieties on seedling vigor index 2 .

\begin{tabular}{|c|c|c|c|c|}
\hline \multirow{2}{*}{ Variety } & \multirow{2}{*}{ PT } & \multicolumn{3}{|c|}{ Priming durations } \\
\hline & & & 6 & 12 \\
\hline \multirow[t]{4}{*}{ Belessa 95} & $\mathrm{GA}_{3}$ & $20693^{\text {abcdef }}$ & $21147^{\text {abcdef }}$ & $21587^{\text {abcde }}$ \\
\hline & $\mathrm{KH}_{2} \mathrm{PO}_{4}$ & $20393^{\text {abcdef }}$ & $15153^{\mathrm{hi}}$ & $18087^{\text {defghi }}$ \\
\hline & Water & $18320^{\text {cdefghi }}$ & $23027^{\mathrm{ab}}$ & $23673^{\mathrm{a}}$ \\
\hline & Control & $18320^{\text {cdefghi }}$ & $18320^{\text {cdefghi }}$ & $18320^{\text {cdefghi }}$ \\
\hline \multirow[t]{4}{*}{ Gishema } & $\mathrm{GA}_{3}$ & $15633^{\mathrm{hi}}$ & $20107^{\text {abcdefg }}$ & $21580^{\text {abcde }}$ \\
\hline & $\mathrm{KH}_{2} \mathrm{PO}_{4}$ & $17693^{\text {efghi }}$ & $16953^{\text {fghi }}$ & $15273^{\mathrm{kl}}$ \\
\hline & Water & $22073^{\text {abcd }}$ & $22833^{\mathrm{abc}}$ & $21460^{\text {bcd }}$ \\
\hline & Control & $14140^{\mathrm{i}}$ & $14140^{\mathrm{i}}$ & $14140^{\mathrm{i}}$ \\
\hline \multirow[t]{4}{*}{ Wello } & $\mathrm{GA}_{3}$ & $20693^{\text {abcdef }}$ & $21000^{\text {abcdef }}$ & $20260^{\text {abcdef }}$ \\
\hline & $\mathrm{KH}_{2} \mathrm{PO}_{4}$ & $21720^{\text {abcde }}$ & $15900^{\text {ghi }}$ & $15273^{\mathrm{hi}}$ \\
\hline & Water & $18733^{\text {cdefgh }}$ & $22087^{\text {abcd }}$ & $21460^{\text {abcde }}$ \\
\hline & Control & $19053^{\text {bcdefg }}$ & $19053^{\text {bcdefg }}$ & $19053^{\text {bcdefg }}$ \\
\hline LSD & & & & 4291.1 \\
\hline $\mathrm{CV}$ & & & & 6.80 \\
\hline
\end{tabular}

Where, PT $=$ Priming types, $\mathrm{GA}_{3}=$ Gibberellic acid, $\mathrm{KH}_{2} \mathrm{PO}_{4}=$ Potassium dihydrophosphate. Means followed by the same letter (s) at each column and row are not significantly different from each other at 0.05 level of probability.

\section{vi. Speed of Germination}

There was highly significance difference $(\mathrm{P} \leq 0.01)$ among varieties, priming type, duration of priming and their interaction effects on Speed of Germination. The highest Speed of Germination was recorded when Wello variety primed with water for $6 \mathrm{hr}$ (42.89) followed by Belessa 95 variety primed withGA $\mathrm{A}_{3}$ and water for $6 \mathrm{hr}$ (42.38) and Belessa 95 variety primed with water for $0 \mathrm{hr}$ (42.33) whereas the lowest speed of Germination was observed on Gishema variety primed with $\mathrm{KH}_{2} \mathrm{PO}_{4}$ for $0 \mathrm{hr}$ (33.99) and unprimed Gishema variety (34.17) which is at par with Gishema primed with $\mathrm{KH}_{2} \mathrm{PO}_{4}$ for $12 \mathrm{hr}$ (34.20), Belessa 95 variety primed with $\mathrm{KH}_{2} \mathrm{PO}_{4}$ for $0 \mathrm{hr}$ (34.69), unprimed Belessa95 variety (34.78) and unprimed Wello variety (35.22) (Table 9). Primed variety showed an increased speed of germination over the control. This finding is in agreement with the previous finding that concluded Soybean Seed primed with $\mathrm{GA}_{3}(20 \mathrm{ppm})$ recorded significantly higher speed of germination (59.00) followed by $\mathrm{CaCl}_{2} \cdot 2 \mathrm{H}_{2} \mathrm{O}(0.5 \%)$ and $\mathrm{KH}_{2} \mathrm{PO}_{4}(50 \mathrm{ppm})$ primed [49]. Similar finding concluded that chickpea variety primed with water effectively increased the speed of germinations over the control and osmopriming [30]. Likewise, another finding reported that significant improvements in the Germination rate of soybean seeds due to hydro priming over unprimed one [40]. Similarly, the previous finding reported that seed priming resulted antioxidant increment as glutathione and ascorbate in seed these enzymes make more germination speed via reduction of lipid per oxidation activity [51]. It has been declared that priming had been resulted in more germination speed especially in drought stress, saline stress and low temperatures in sorghum, sunflower and melon [52] and [53]. The probable reason for early emergence of the primed seed maybe due to the completion of pre-germination metabolic activities making the seed ready for radicle protrusion.

Table 9. Interaction effects of priming types, duration and varieties on Speed of Germination.

\begin{tabular}{|c|c|c|c|c|}
\hline \multirow{2}{*}{ Variety } & \multirow{2}{*}{ PT } & \multicolumn{3}{|c|}{ Priming durations } \\
\hline & & $\mathbf{0}$ & 6 & 12 \\
\hline \multirow[t]{4}{*}{ Belessa 95} & $\mathrm{GA}_{3}$ & 39.90 & $42.38^{\text {av }}$ & $39.69^{-1}$ \\
\hline & $\mathrm{KH}_{2} \mathrm{PO}_{4}$ & $34.69^{\mathrm{M}}$ & $38.68^{5^{111}}$ & $39.48^{-15}$ \\
\hline & Water & $42.33^{\text {uv }}$ & $42.38^{\text {uv }}$ & $41.83^{\text {บ }}$ \\
\hline & Control & $34.78^{\mathrm{M}}$ & $34.78^{\mathrm{MI}}$ & $34.78^{\mathrm{MI}}$ \\
\hline \multirow[t]{4}{*}{ Wello } & $\mathrm{GA}_{3}$ & $37.79^{\circ}$ & $39.28^{10^{11}}$ & $38.63^{5+1}$ \\
\hline & $\mathrm{KH}_{2} \mathrm{PO}_{4}$ & $37.98^{-}$ & $40.05^{-1}$ & $40.38^{\text {uc }}$ \\
\hline & Water & $41.28^{u}$ & $42.89^{u}$ & $41.85^{\mathrm{U}}$ \\
\hline & Control & $35.22^{12}$ & $35.22^{\mathrm{Ju}}$ & $35.22^{12}$ \\
\hline \multirow[t]{4}{*}{ Gishema } & $\mathrm{GA}_{3}$ & $40.14^{-1}$ & $39.84^{-1}$ & $38.42^{111}$ \\
\hline & $\mathrm{KH}_{2} \mathrm{PO}_{4}$ & $33.99^{1}$ & $35.17^{\text {Jn }}$ & $34.20^{1}$ \\
\hline & Water & $35.93^{\mathrm{J}}$ & $41.87^{\circ \mathrm{U}}$ & $41.87^{\text {Uu }}$ \\
\hline & Control & $34.17^{1}$ & $34.17^{1}$ & $34.17^{1}$ \\
\hline LSD & & & & 0.95 \\
\hline $\mathrm{CV}$ & & & & 3.54 \\
\hline
\end{tabular}

Where, $\mathrm{PT}=$ Priming type, $\mathrm{GA}_{3}=$ Gibberellic acid, $\mathrm{KH}_{2} \mathrm{PO}_{4}=$ Potassium dihydrophosphate. Means followed by the same letter (s) at each column and row are not significantly different from each other at 0.05 level of Probability.

\section{vii.Electrical conductivity (EC)}

Highly significance difference $(\mathrm{P} \leq 0.01)$ in electrical conductivity reading was observed among varieties, priming type, duration of priming and between their interaction effects. The highest electrical conductivity was observed for Belessa 95variety primed with $\mathrm{GA}_{3}$ for $6 \mathrm{hr}\left(496.99 \mu \mathrm{Scm}^{-1} \mathrm{~g}^{-1}\right)$ and Wello variety primed with water for $12 \mathrm{hr}\left(491.78 \mu \mathrm{Scm}^{-}\right.$ ${ }^{1} \mathrm{~g}^{-1}$ ) followed by Gishema variety primed with water for $0 \mathrm{hr}$ $\left(441.98 \mu \mathrm{Scm}^{-1} \mathrm{~g}^{-1}\right)$ and Wello variety primed with $\mathrm{GA}_{3}$ for Ohr (439.17). The lowest EC reading was recorded when Wello variety primed with water for $6 \mathrm{hr}\left(220.82 \mu \mathrm{Scm}^{-1} \mathrm{~g}^{-1}\right)$ and Belessa 95variety primed with Water for $0 \mathrm{hr}(221.87$ $\mu \mathrm{scm}^{1} \mathrm{~g}^{1}$ ) followed by Belessa 95variety primed with $\mathrm{GA}_{3}$ for $0 \mathrm{hr}\left(253.43 \mu \mathrm{Scm}^{-1} \mathrm{~g}^{-1}\right)$, Gishama variety primed with $\mathrm{GA}_{3}$ for $0 \mathrm{hr}\left(258.44 \mu \mathrm{Scm}^{-1} \mathrm{~g}^{-1}\right)$ and unprimed Belessa 95 variety $\left(281.03 \mu \mathrm{Scm}^{-1} \mathrm{~g}^{-1}\right)$ whereas the other gave an intermediate values (Table 10).

The highest EC reading was observed on Wello variety $\left(377.1 \mu \mathrm{Scm}^{-1} \mathrm{~g}^{-1}\right)$ and Belessa 95 variety $\left(358.25 \mu \mathrm{Scm}^{-1} \mathrm{~g}^{-1}\right)$ 
whereas the lowest EC was observed on Gishama variety (356.25 $\left.\mu \mathrm{Scm}^{-1} \mathrm{~g}^{-1}\right)$ the variation amongst varieties in their response to priming might be related to genetic differences that makes them whether susceptible or not to fungal disease that leads to an increment in EC readings. The highest electrical conductivity might be due to deterioration of the seed as the result of seed borne fungal diseases which leads to increase the leachates from the seed. This finding was in agreement with the previous finding which concluded that chickpea seeds primed with water and $0.5 \% \mathrm{KH}_{2} \mathrm{PO}_{4}$ had the potential to reduce seed leachates in all chickpea varieties [30]. According to previous study loss of membrane integrity is a key physiological symptom of seed damage and it is measured by electrical conductivity of seed leachates and also seed priming presumably allowed some repairs of damage to membrane caused deterioration [54]. Therefore, seed that may deteriorate during maturation and/or storage and thus undergo repair of damaged parts during imbibitions indicates that seeds could benefit more from priming treatments [55]. The lowest electrical conductivity of seed leachates treated seed may be due to beneficial effects of priming in strengthening the cell membrane integrity and permeability [56]. On the contrary, the decrease in leachates as the result of priming treatments has been suggested to come from membrane repair mechanisms that occur during soaking [57].

Table 10. Interaction effects of priming types, duration and varieties on Electrical conductivity.

\begin{tabular}{|c|c|c|c|c|}
\hline \multirow{2}{*}{ Variety } & \multirow{2}{*}{ PT } & \multicolumn{3}{|c|}{ Priming durations } \\
\hline & & 0 & 6 & 12 \\
\hline \multirow[t]{4}{*}{ Belessa 95} & $\mathrm{GA}_{3}$ & $253.43^{\mathrm{jk}}$ & $496.99^{\mathrm{a}}$ & $409.53^{\text {bcde }}$ \\
\hline & $\mathrm{KH}_{2} \mathrm{PO}_{4}$ & $374.29^{\mathrm{efgh}}$ & $358.50^{\mathrm{h}}$ & $390.57^{\text {defgh }}$ \\
\hline & Water & $221.87^{\mathrm{k}}$ & $397.17^{\text {defg }}$ & $402.54^{\text {cdef }}$ \\
\hline & Control & $281.03^{\mathrm{ij}}$ & $281.03^{\mathrm{ij}}$ & $281.03^{\mathrm{ij}}$ \\
\hline \multirow[t]{4}{*}{ Wello } & $\mathrm{GA}_{3}$ & $439.17^{\mathrm{bc}}$ & $361.17^{\mathrm{gh}}$ & $361.58^{\mathrm{gh}}$ \\
\hline & $\mathrm{KH}_{2} \mathrm{PO}_{4}$ & $396.89^{\text {defg }}$ & $368.78^{\text {fgh }}$ & $369.84^{\mathrm{fgh}}$ \\
\hline & Water & $220.82^{k}$ & $399.74^{\text {defg }}$ & $491.78^{\mathrm{a}}$ \\
\hline & Control & $360.74^{\mathrm{gh}}$ & $360.74^{\mathrm{gh}}$ & $360.74^{\mathrm{gh}}$ \\
\hline \multirow[t]{4}{*}{ Gishema } & $\mathrm{GA}_{3}$ & $258.44^{\mathrm{jk}}$ & $298.11^{\mathrm{i}}$ & $308.42^{\mathrm{i}}$ \\
\hline & $\mathrm{KH}_{2} \mathrm{PO}_{4}$ & $375.09^{\text {efgh }}$ & $369.57^{\text {fgh }}$ & $359.38^{\mathrm{h}}$ \\
\hline & Water & $441.98^{b}$ & $423.29^{\mathrm{bcd}}$ & $375.09^{\text {efgh }}$ \\
\hline & Control & $356.24^{\mathrm{h}}$ & $356.24^{\mathrm{h}}$ & $356.24^{\mathrm{h}}$ \\
\hline LSD & & & & 38.97 \\
\hline $\mathrm{CV}$ & & & & 3.33 \\
\hline
\end{tabular}

Where, PT $=$ Priming type $\mathrm{GA}_{3}=$ Gibberellic acid, $\mathrm{KH}_{2} \mathrm{PO}_{4}=$ Potassium dihydrophosphate. Means followed by the same letter (s) at each column and row are not significantly different from each other at 0.05 level of probability

\section{viii. Field Emergence index}

There was highly significance difference $(\mathrm{P} \leq 0.01)$ among varieties, priming type and duration and their interactions effects for on field emergence index. The highest emergence index was recorded on Belessa 95variety primed with water for $6 \mathrm{hr}$ (31.89) which is at par with Belessa95 variety primed with $\mathrm{GA}_{3}$ for $6 \mathrm{hr}$ (31.74) followed by Wello variety primed with water for $12 \mathrm{hr}(30.81)$, for $6 \mathrm{hr}$ (30.78) and Belessa95 variety primed with $\mathrm{GA}_{3}$ for $12 \mathrm{hr}(30.68)$ whereas the lowest emergence index was observed on un primed Wello (14.87), unprimed Belessa95 variety (17.73) and unprimed Gishema variety (18.19) which is at par with Belessa95 variety primed with $\mathrm{KH}_{2} \mathrm{PO}_{4}$ for $0 \mathrm{hr}$ (18.64). The highest emergence index was observed on Wello variety (27.40) and Belessa95 variety (27.08) whereas the lowest emergence index was observed on Gishema variety (24.76) (Table11). The faster emergence of seeds primed with $\mathrm{GA}_{3}$ may be due to its stimulation effect in the formation of enzymes which are important in the early phases of germination which help for a fast radicle protrusion and hypocotyl elongation to penetrate the soil up. The variation amongst varieties in their response to priming might be related to genetic differences. This is in agreement with the previous findings that found hydro priming enhanced seedling establishments and early vigor of upland rice, maze and chickpea resulting in faster developments [32] and [58]. According to the previous observation physiological basis for increasing seedling emergence of primed seeds might be due to early DNA replication, increased RNA and Protein synthesis, greater ATP availability, faster embryo growth, repairs of deteriorated seed parts and reduce leakage of metabolites compared to the control [59]. In addition to initiating metabolic events priming may also leach germination inhibitors from the seeds such a removal of germination inhibitors which reduce the germination time so that increased seedling emergence index of primed seeds with respect to the control.

Table 11. Interaction effects of priming types, duration and varieties on Field Emergence index.

\begin{tabular}{|c|c|c|c|c|}
\hline \multirow{2}{*}{ Variety } & \multirow{2}{*}{ PT } & \multicolumn{3}{|c|}{ Priming durations } \\
\hline & & $\mathbf{0}$ & 6 & 12 \\
\hline \multirow[t]{4}{*}{ Belessa 95} & $\mathrm{GA}_{3}$ & $29.18^{\text {abcdefg }}$ & $31.74^{\mathrm{ab}}$ & $30.68^{\mathrm{abcd}}$ \\
\hline & $\mathrm{KH}_{2} \mathrm{PO}_{4}$ & $18.64^{\mathrm{kl}}$ & $26.11^{\text {fghi }}$ & $27.18^{\text {efghi }}$ \\
\hline & Water & $28.62^{\text {abcdefg }}$ & $31.89^{\mathrm{a}}$ & $29.06^{\text {abcdefg }}$ \\
\hline & Control & $17.73^{\mathrm{lm}}$ & $17.73^{\mathrm{lm}}$ & $17.73^{\mathrm{lm}}$ \\
\hline \multirow[t]{4}{*}{ Wello } & $\mathrm{GA}_{3}$ & $27.36^{\text {defghi }}$ & $29.09^{\text {abcdefg }}$ & $30.04^{\text {abcde }}$ \\
\hline & $\mathrm{KH}_{2} \mathrm{PO}_{4}$ & $24.77^{\mathrm{hij}}$ & $28.72^{\text {abcdefg }}$ & $29.30^{\text {abcdef }}$ \\
\hline & Water & $24.89^{\mathrm{hij}}$ & $30.78^{\mathrm{abc}}$ & $30.81^{\mathrm{abc}}$ \\
\hline & Control & $14.87^{\mathrm{m}}$ & $14.87^{\mathrm{m}}$ & $14.87^{\mathrm{m}}$ \\
\hline \multirow[t]{4}{*}{ Gishema } & $\mathrm{GA}_{3}$ & $24.71^{\mathrm{hij}}$ & $29.89^{\text {abcde }}$ & $28.37^{\text {bcdefg }}$ \\
\hline & $\mathrm{KH}_{2} \mathrm{PO}_{4}$ & $20.22^{\mathrm{kl}}$ & $24.32^{\mathrm{ij}}$ & $25.81^{\text {ghi }}$ \\
\hline & Water & $21.89^{\mathrm{jk}}$ & $28.05^{\text {cdefgh }}$ & $29.50^{\text {abcdef }}$ \\
\hline & Control & $18.19^{\mathrm{lm}}$ & $18.19^{\mathrm{lm}}$ & $18.19^{\mathrm{lm}}$ \\
\hline LSD & & & & 3.40 \\
\hline $\mathrm{CV}$ & & & & 4.00 \\
\hline
\end{tabular}

Where, PT $=$ Priming type $\mathrm{GA}_{3}=$ Gibberellic acid, $\mathrm{KH}_{2} \mathrm{PO}_{4}=$ Potassium dihydrophosphate. Means followed by the same letter (s) at each column and row are not significantly different from each other at 0.05 level of probability.

\subsection{Correlation Coefficients Between Field Emergence and Other Vigor Parameters}

Correlation analysis between field emergence and other vigor parameters showed that there was highly significant $(\mathrm{P} \leq 0.01)$ correlation between field emergence index with seedling dry weight, standard germination, speed of germination, shoot length, electrical conductivity and seedling vigor index 1. (Table 12). There were strongly positive correlation between field emergence index with that of electrical conductivity $(\mathrm{r}=0.22)$, speed of germination 
$(\mathrm{r}=0.62)$, shoot length $(\mathrm{r}=0.50)$, seedling vigor index 1 $(\mathrm{r}=0.42)$, seedling dry weight $(\mathrm{r}=0.40)$ and standard germination $(\mathrm{r}=0.39)$ (Table 12).

This finding was in agreement with the previous findings which reported that the relationship between emergence index and vigor parameters such as speed of germination vigor index 1 and root length was significant and the association of speed of germination and root length with emergence index were strong $(\mathrm{r}=0.70$, and $\mathrm{r}=-0.65$ respectively) [60]. According to previous finding electrical conductivity test was best correlated with field emergence than the other laboratory seed quality tests [61] and [62]. Similarly, another report concluded that vigor especially electrical conductivity test was a good predictor of field emergence and showed a better correlation with field emergence index than the standard germination test [63].

Table 12. Correlation Coefficients (r) between field emergence and other vigor parameters.

\begin{tabular}{|c|c|c|c|c|c|c|c|c|c|c|}
\hline & EC & FEI & MC & RL & SDW & SG & SL & SPG & SVI1 & SVI2 \\
\hline FEI & $0.22 * *$ & 1 & & & & & & & & \\
\hline $\mathrm{MC}$ & $0.15^{\mathrm{NS}}$ & $0.03^{\mathrm{NS}}$ & 1 & & & & & & & \\
\hline RL & $0.15^{\mathrm{NS}}$ & $-0.11^{\mathrm{NS}}$ & $0.22 *$ & 1 & & & & & & \\
\hline SG & $0.14^{\mathrm{NS}}$ & $0.39 * *$ & $-0.03^{\mathrm{NS}}$ & $0.16^{\mathrm{NS}}$ & $0.18^{\mathrm{NS}}$ & 1 & & & & \\
\hline SL & $0.27 * *$ & $0.50 * *$ & $0.25^{*}$ & $0.17^{\mathrm{NS}}$ & $0.18^{\mathrm{NS}}$ & $-0.01^{\mathrm{NS}}$ & 1 & & & \\
\hline SPG & $0.09^{\mathrm{NS}}$ & $0.62 * *$ & $-0.04^{\mathrm{NS}}$ & $0.07^{\mathrm{NS}}$ & $0.38 * *$ & $0.42 * *$ & $0.11^{\mathrm{NS}}$ & 1 & & \\
\hline SVI2 & $0.27 * *$ & $0.42 * *$ & $-0.08^{\mathrm{NS}}$ & $0.15^{\mathrm{NS}}$ & $0.97 * *$ & $0.40 * *$ & $0.16^{\mathrm{NS}}$ & $0.46^{* *}$ & $0.04^{\mathrm{NS}}$ & 1 \\
\hline
\end{tabular}

Note, ${ }^{\mathrm{NS}} * *$ and $*$ indicates non-significant, highly significant at $1 \%$ and significant at $5 \%$ level of probability respectively. EC $=$ electrical conductivity, $\mathrm{FEI}=$ field emergency index, $\mathrm{MC}=$ moisture contents, $\mathrm{SDW}=$ seedling dry weight, $\mathrm{SG}=$ standard germination, $\mathrm{SL}=\mathrm{shoot}$ length $\mathrm{RL}=$ root length $\mathrm{SPG}=\mathrm{speed}$ of germination, $\mathrm{SVI} 1=$ seedling vigor index 1 and $\mathrm{SVI} 2=$ seedling vigor index 2

\subsection{Seed health Testing}

As soybean acreages have expanded throughout the world, diseases have increased in incidence and severity. Some are previously undescribed diseases others were introduced from the orient or other production areas where they have been known for many years. Generally one or more diseases can be found in fields wherever soybeans are grown and all parts of soybean plants are susceptible to a number of pathogens which reduce the quality and/or quantity of seed yields. Seeds are basic input of Agricultural production and hence should be free from seed-borne diseases. Generally, seedborne microorganisms may either deteriorate seed in storage or transmit diseases to new crop early in the season. In this study, eighteen fungi and one bacterium were found to be associated with Soybean varieties by using the agar plate test method. Soybean seed-borne diseases occurred in the study included Colletotrichum dematium, Aspergillus flavus, Aspergillus niger, Fusarium oxysporum, Penicillium spp, Alternaria spp, Tricodormal spp, Rhizoctonia solani, Pythium spp, Cladosporium spp, Curvularia lunata, Rhizoctonia bataticola, Rhizopus spp, Macrophomina spp, yeast, Chaetomium spp, Sphacelomia glycines andXanthomonas campestris $p v$ phaseoli. Generally in this study around four to eight different types of fungal species was observed on each treatment (Table 13). The higher detected percentage infection, fungi of the seed was observed on Tricodormal spp (80\%) on unprimed Belessa 95 variety followed by Wello variety which was primed with $\mathrm{KH}_{2} \mathrm{PO}_{4}$ for $6 \mathrm{hr}(70 \%)$ and Wello variety primed with water for $6 \mathrm{hr}$ (60\%) followed by Aspergillus niger (70\%) on Belessa 95 variety primed with $\mathrm{KH}_{2} \mathrm{PO}_{4}$ for $0 \mathrm{hr}$, on Gishema variety primed with $\mathrm{KH}_{2} \mathrm{PO}_{4}$ for $0 \mathrm{hr}(60 \%)$, on Wello variety primed with water for $0 \mathrm{hr}(60 \%)$, onBelessa 95 variety primed with water for $6 \mathrm{hr}(60 \%)$ and Fusarium oxysporum $(70 \%)$ on
Gishema variety primed with $\mathrm{KH}_{2} \mathrm{PO}_{4}$ for $0 \mathrm{hr}$ and Chaetomium spp (60\%) on unprimed Wello variety. The other zero values were non detected seed-borne diseases on three of soybean varieties and different seed treatment (Table 13).

In Bangladesh study were undertaken to detect the seedborne fungi associated with soybean seeds altogether ten fungi comprising nine genera namely Alternaria alternata, Aspergillus flavus, Aspergillus niger, Cheatomium globosum, Colletotrichum dematium, Curvularia lunata, Fusarium oxysporum, Macrophomina phasaelina, Penicillium sp. And Rhizopus stolonifer were isolated from soybean seed samples. Among the isolated fungi Aspergillus flavus was most prevalent followed by Aspergillus niger Fusarium oxysporum, Colletotrichum dematium and Penicillium sp ranged from 10$72 \%$, 4-28\%, 4-38\%, 0-22\%, 0-17\%, respectively. The highest incidence of $A$. flavus, $F$. oxysporum, A. niger, $A$. alternata, C. dematium, Penicillium sp. C. globosum, $C$. lunataand $R$. stoloniferand M. phasaelina was 72\%, 38\%, $28 \%, 26 \%, 22 \%, 21 \%, 11 \%, 10 \%$ and $4 \%$ respectively [64].

Similarly, A total of 120 representative soybean seed samples (cv. JS - 335) were collected from major soybean growing districts of Andhra Pradesh viz., Adilabad (60 samples) and Nizamabad (60 samples) during Rainy season 2012. Per cent total incidence of seed mycoflora in Nizamabad and Adilabad districts ranged from 30 to $49.2 \%$ and 23.6 to $45.0 \%$ by blotter method, 14.8 to $28.1 \%$ and 11.6 to $22.1 \%$ by 2,4 - D blotter method, 11.8 to $19.3 \%$ and 9.5 to $16.2 \%$ by deep freeze blotter method, 13.1 to $37 \%$ and 15.4 to $26.4 \%$ by agar plate method, respectively. Out of nine fungal species recorded, Macrophomina phaseolina was found predominant in the samples analyzed from two districts (8.5 to $28.5 \%)$, while the occurrence of Cladosporium spp. $(0.3$ to $0.5 \%)$ was least. Seed transmission of $M$. phaseolina in apparently healthy soybean seeds (cv. JS 335) was $6 \%$ and $8 \%$ and in artificially 
inoculated soybean seeds $(38.5 \%$ and $49 \%)$ and in naturally infected soybean seeds (32\% and 43.1\%). [64]. Moreover, another report suggested that many more and most of these seed-borne fungi from chickpea seeds grown in Ethiopia [65].
Similar results were reported for field pea and it can be concluded that surface sterilization of seeds substantially reduces the fungi found on the surface of the seeds [66].

Table 13. Interaction effects of Variety, priming types, and durations on fungi associations (\%).

\begin{tabular}{|c|c|c|c|c|c|c|c|c|c|c|c|c|c|}
\hline \multirow[b]{2}{*}{ Variety } & \multirow{2}{*}{$\begin{array}{l}\text { Priming } \\
\text { treatments }\end{array}$} & \multirow{2}{*}{\multicolumn{2}{|c|}{$\begin{array}{l}\text { Priming } \\
\text { durations }\end{array}$}} & \multicolumn{10}{|c|}{ Types of Fungal species } \\
\hline & & & & \multicolumn{2}{|c|}{ Colletotrichumdematium } & $\begin{array}{l}\text { Aspergillus } \\
\text { flavus }\end{array}$ & $\begin{array}{l}\text { Aspergillus } \\
\text { niger }\end{array}$ & $\begin{array}{l}\text { Fusarium } \\
\text { oxysporum }\end{array}$ & $\begin{array}{l}\text { Penicillium } \\
\text { spp }\end{array}$ & \multicolumn{2}{|c|}{$\begin{array}{l}\text { Alternaria } \\
\text { spp }\end{array}$} & $\begin{array}{l}\text { Tricodormal } \\
\text { spp }\end{array}$ & $\begin{array}{l}\text { Rhizoctonia } \\
\text { solani }\end{array}$ \\
\hline Belessa95 & unprimed & Contrl & & 0 & & 10 & 30 & 20 & 20 & 30 & & 80 & 0 \\
\hline Belessa95 & $\mathrm{GA}_{3}$ & 0 & & 40 & & 30 & 10 & 20 & 0 & 0 & & 0 & 0 \\
\hline Belessa95 & $\mathrm{GA}_{3}$ & 6 & & 0 & & 30 & 20 & 20 & 30 & 0 & & 0 & 20 \\
\hline Belessa95 & $\mathrm{GA}_{3}$ & 12 & & 10 & & 0 & 50 & 0 & 20 & 0 & & 0 & 20 \\
\hline Belessa95 & $\mathrm{KH}_{2} \mathrm{PO}_{4}$ & 0 & & 30 & & 50 & 50 & 20 & 0 & 0 & & 0 & 0 \\
\hline Belessa95 & $\mathrm{KH}_{2} \mathrm{PO}_{4}$ & 6 & & 50 & & 30 & 70 & 30 & 0 & 0 & & 0 & 0 \\
\hline Belessa95 & $\mathrm{KH}_{2} \mathrm{PO}_{4}$ & 12 & & 40 & & 30 & 30 & 40 & 0 & 0 & & 0 & 0 \\
\hline Belessa95 & Water & 0 & & 40 & & 0 & 0 & 40 & 10 & 20 & & 20 & 0 \\
\hline Belessa95 & Water & 6 & & 30 & & 0 & 60 & 50 & 10 & 0 & & 0 & 0 \\
\hline Belessa95 & Water & 12 & & 50 & & 10 & 10 & 20 & 0 & 0 & & 0 & 0 \\
\hline Wello & unprimed & Contrl & & 0 & & 0 & 20 & 0 & 10 & 0 & & 0 & 10 \\
\hline Wello & $\mathrm{GA}_{3}$ & 0 & & 40 & & 30 & 30 & 40 & 0 & 0 & & 0 & 0 \\
\hline Wello & $\mathrm{GA}_{3}$ & 6 & & 0 & & 10 & 10 & 20 & 0 & 0 & & 0 & 0 \\
\hline Wello & $\mathrm{GA}_{3}$ & 12 & & 0 & & 30 & 0 & 0 & 20 & 30 & & 0 & 20 \\
\hline Wello & $\mathrm{KH}_{2} \mathrm{PO}_{4}$ & 0 & & 0 & & 20 & 20 & 0 & 10 & 20 & & 0 & 0 \\
\hline Wello & $\mathrm{KH}_{2} \mathrm{PO}_{4}$ & 6 & & 0 & & 10 & 10 & 10 & 40 & 0 & & 70 & 0 \\
\hline Wallo & $\mathrm{KH}_{2} \mathrm{PO}_{4}$ & 12 & & 0 & & 0 & 40 & 0 & 10 & 10 & & 0 & 0 \\
\hline Wello & Water & 0 & & 20 & & 0 & 60 & 20 & 0 & 10 & & 0 & 0 \\
\hline Wello & Water & 6 & & 0 & & 20 & 20 & 0 & 10 & 20 & & 60 & 0 \\
\hline Wello & Water & 12 & & 10 & & 0 & 10 & 40 & 0 & 0 & & 0 & 0 \\
\hline Gishema & unprimed & Contrl & & 0 & & 10 & 0 & 50 & 20 & 0 & & 0 & 0 \\
\hline Gishema & $\mathrm{GA}_{3}$ & 0 & & 40 & & 10 & 20 & 20 & 0 & 20 & & 0 & 0 \\
\hline Gishema & $\mathrm{GA}_{3}$ & 6 & & 20 & & 0 & 10 & 40 & 0 & 30 & & 0 & 0 \\
\hline Gishema & $\mathrm{GA}_{3}$ & 12 & & 20 & & 20 & 20 & 0 & 30 & 0 & & 0 & 0 \\
\hline Gishema & $\mathrm{KH}_{2} \mathrm{PO}_{4}$ & 0 & & 0 & & 50 & 60 & 70 & 0 & 0 & & 0 & 0 \\
\hline Gishema & $\mathrm{KH}_{2} \mathrm{PO}_{4}$ & 6 & & 0 & & 10 & 20 & 50 & 0 & 30 & & 0 & 0 \\
\hline Gishema & $\mathrm{KH}_{2} \mathrm{PO}_{4}$ & 12 & & 20 & & 0 & 0 & 10 & 0 & 0 & & 0 & 0 \\
\hline Gishema & Water & 0 & & 0 & & 0 & 0 & 10 & 0 & 20 & & 0 & 0 \\
\hline Gishema & Water & 6 & & 0 & & 10 & 20 & 50 & 20 & 0 & & 0 & 0 \\
\hline Gishema & Water & 12 & & 30 & & 20 & 0 & 40 & 20 & 30 & & 0 & 0 \\
\hline $\begin{array}{l}\text { Pythium } \\
\text { spp } \\
\end{array}$ & $\begin{array}{l}\text { Cladospo } \\
\text { spp }\end{array}$ & prium & $\begin{array}{l}\text { Cuı } \\
\text { lun }\end{array}$ & $\begin{array}{l}\text { rvularia } \\
\text { lata }\end{array}$ & $\begin{array}{l}\text { Rhizoctonia } \\
\text { bataticola }\end{array}$ & $\begin{array}{l}\text { Rhizopus } \\
\text { spp }\end{array}$ & $\begin{array}{l}\text { Macrophomin } \\
\text { spp }\end{array}$ & yeast & $\begin{array}{l}\text { Chaetom } \\
\text { spp }\end{array}$ & nium & $\begin{array}{l}\text { Spha } \\
\text { glyci }\end{array}$ & $\begin{array}{l}\text { acelomia } \\
\text { ines }\end{array}$ & $\begin{array}{l}\text { Kanthomonas } \\
\text { ampestris }\end{array}$ \\
\hline 0 & 0 & & 40 & & 0 & 0 & 0 & 20 & 0 & & 0 & 0 & \\
\hline 30 & 10 & & 30 & & 0 & 0 & 0 & 0 & 0 & & 0 & 0 & \\
\hline 30 & 0 & & 20 & & 0 & 0 & 0 & 30 & 0 & & 0 & 20 & 0 \\
\hline 0 & 0 & & 0 & & 0 & 0 & 0 & 20 & 0 & & 0 & 20 & 0 \\
\hline 0 & 0 & & 10 & & 0 & 0 & 0 & 0 & 0 & & 0 & 0 & \\
\hline 0 & 0 & & 0 & & 0 & 0 & 0 & 0 & 0 & & 0 & 0 & \\
\hline 0 & 0 & & 0 & & 0 & 0 & 0 & 0 & 0 & & 0 & 0 & \\
\hline 0 & 10 & & 0 & & 10 & 0 & 0 & 30 & 0 & & 0 & 0 & \\
\hline 0 & 0 & & 0 & & 0 & 10 & 0 & 50 & 0 & & 0 & 0 & \\
\hline 0 & 0 & & 20 & & 0 & 0 & 20 & 0 & 0 & & 0 & 0 & \\
\hline 0 & 0 & & 0 & & 0 & 0 & 0 & 30 & 60 & & 0 & 0 & \\
\hline 0 & 0 & & 0 & & 0 & 0 & 0 & 0 & 0 & & 0 & 0 & \\
\hline 30 & 10 & & 30 & & 0 & 0 & 0 & 0 & 0 & & 0 & 0 & \\
\hline 0 & 0 & & 0 & & 30 & 0 & 0 & 0 & 0 & & 0 & 0 & \\
\hline 10 & 0 & & 20 & & 0 & 0 & 0 & 0 & 0 & & 0 & 0 & \\
\hline 0 & 0 & & 0 & & 10 & 0 & 50 & 10 & 10 & & 0 & 0 & \\
\hline 30 & 0 & & 0 & & 0 & 0 & 0 & 0 & 20 & & 0 & 0 & \\
\hline 20 & 20 & & 0 & & 0 & 0 & 0 & 10 & 0 & & 0 & 0 & \\
\hline 10 & 0 & & 20 & & 0 & 0 & 0 & 0 & 0 & & 0 & 0 & \\
\hline 30 & 0 & & 0 & & 0 & 0 & 0 & 0 & 0 & & 50 & 0 & \\
\hline 40 & 0 & & 0 & & 0 & 0 & 60 & 20 & 0 & & 0 & 0 & \\
\hline 20 & 0 & & 0 & & 0 & 0 & 0 & 0 & 20 & & 0 & 0 & \\
\hline 10 & 0 & & 0 & & 0 & 20 & 0 & 0 & 0 & & 0 & 0 & \\
\hline 0 & 0 & & 20 & & 0 & 0 & 50 & 0 & 0 & & 0 & 0 & \\
\hline 30 & 0 & & 0 & & 0 & 0 & 0 & 10 & 0 & & 0 & 0 & \\
\hline
\end{tabular}




\begin{tabular}{lllllllll}
\hline $\begin{array}{l}\text { Pythium } \\
\text { spp }\end{array}$ & $\begin{array}{l}\text { Cladosporium } \\
\text { spp }\end{array}$ & $\begin{array}{l}\text { Curvularia } \\
\text { lunata }\end{array}$ & $\begin{array}{l}\text { Rhizoctonia } \\
\text { bataticola }\end{array}$ & $\begin{array}{l}\text { Rhizopus } \\
\text { spp }\end{array}$ & $\begin{array}{l}\text { Macrophomina } \\
\text { spp }\end{array}$ & $\begin{array}{l}\text { yeast } \\
\text { Chaetomium }\end{array}$ & $\begin{array}{l}\text { Sphacelomia } \\
\text { spp }\end{array}$ & $\begin{array}{l}\text { Xanthomonas } \\
\text { campestris }\end{array}$ \\
\hline 40 & 0 & 0 & 10 & 0 & 0 & 30 & 10 & 0 \\
40 & 0 & 0 & 10 & 0 & 0 & 20 & 10 & 0 \\
0 & 0 & 0 & 0 & 0 & 0 & 20 & 10 & 0 \\
0 & 0 & 0 & 0 & 0 & 0 & 20 & 20 & 0 \\
0 & 0 & 0 & 0 & 0 & 0 & 0 & 0 \\
\hline
\end{tabular}

\section{Conclusion and Recommendation}

Priming treatment improves or enhanced most of the measured laboratory parameters of the varieties. In laboratory experiment highly significant $(\mathrm{P} \leq 0.01)$ differences among varieties, priming type, priming durations and between their interaction effects for seedling dry weight, seedling vigor index 2, speed of germinations, electrical conductivity and field emergence index and significant $(\mathrm{P} \leq 0.05)$ difference for seedling vigor index 1 . Highly significant $(\mathrm{P} \leq 0.01)$ differences among priming treatments and significant $(\mathrm{P} \leq 0.05)$ differences among varieties for germinations and root length respectively. The highest standard germinations were observed on Belessa95 varieties (91.27\%) and seed primed with water $(92.67 \%)$, the highest shoot length were observed for Belessa95 varieties primed with $\mathrm{GA}_{3}(16.31 \mathrm{~cm})$ and the highest root length were observed for Belessa95 varieties $(6.98 \mathrm{~cm})$ and seed primed with water $(7.22 \mathrm{~cm})$. The highest seedling dry weight was recorded when Belessa95 variety primed with water for $12 \mathrm{hr}(250 \mathrm{gm})$ and Gishema variety primed with water for $6 \mathrm{hr}(250 \mathrm{gm})$. The highest seedling vigor index1 (SVI-1) was recorded when Gishema variety primed with $\mathrm{KH}_{2} \mathrm{PO}_{4}$ for $6 \mathrm{hr}(2202.20)$, the highest seedling vigor index 2 was recorded when Belessa 95 variety primed with water for $12 \mathrm{hr}$ (23673), the highest Speed of Germination was recorded when Wello variety primed with water for $6 \mathrm{hr}$ (42.89) and the highest emergence index was recorded when Belessa 95 variety primed with water for $6 \mathrm{hr}$ (31.89). Correlation analysis between field emergence and other vigor parameters showed that there was highly significant $(\mathrm{P} \leq 0.01)$ correlation between field emergence index with seedling dry weight, standard germination, speed of germination, shoot length, electrical conductivity and seedling vigor index 1. Eighteen fungi and one bacterium were found to be associated with Soybean varieties these are:-Colletotrichum dematium, Aspergillus flavus, Aspergillus niger, Fusarium oxysporum, Penicillium spp, Alternaria spp, Tricodormal spp, Rhizoctonia solani, Pythium spp, Cladosporium spp, Curvularia lunata, Rhizoctonia bataticola Rhizopus spp, Macrophomina spp, yeast, Chaetomium spp, Sphacelomia glycines and Xanthomonas campestris $p v$ phaseoli. The higher detected percentage infection fungi of the seed were observed on Tricodormal spp (80\%). The two major aflatoxin producing fungi namely Aspergillus flavus and Aspergillus niger was also observed on three of soybean varieties so that, great attentions should be made on using fungi free seeds hence, these aflatoxin cause death to humans and other organisms and another study will be needed to know whether priming can reduce the amount of seed borne fungi and bacterium on soybean varieties.

Generally from laboratory observations soybean varieties primed with water (hydro priming) and $\mathrm{GA}_{3}$ priming Medias showed better results followed by $\mathrm{KH}_{2} \mathrm{PO}_{4}$ on most and each of the measured parameters. Hence, better to recommend for seed growers Hydro priming prior to seed sowing because, simple to use, cost effective and easily available for seed growers to overcome the problems of poor crop emergency and establishments under such adverse environmental conditions comparing to $\mathrm{GA}_{3}$ priming media. However, this study was done only for one season at one location using three varieties, priming media and soaking duration. So that, to give conclusion and recommendations furthermore studies could be made on multiple varieties, priming medias and durations of soaking in research centers, on fields of soybean seed growers and on farmers' fields of different soybean growing areas of Ethiopia.

\section{Acknowledgements}

Above all I would like to thank the Almighty and Merciful GOD for giving me strength, love, health, peace and encouragement in all my life. Without him ever thing was impossible!

I would like to express my deepest thanks to Assosa Agricultural Research Center and Staff particularly to $\mathrm{Mr}$ Bekele Anbassa, Mr Obessa Adugna, Mr Ayehu Alemu and Ms Tigest Addisu for their welcoming approaches, kind assistance, cooperation and unlimited support during my work. I also thank Haramaya University Seed laboratory technicians'Miss Obsitu Abrahim and MSc Pathology laboratory Assistances Mrs Haimanot Bizuneh for their technical support and providing me with the necessary materials during laboratory work.

\section{References}

[1] Lackey, J. A. 1977. A synopsis of Phaseoleae (Leguminosae, Papilionoideae): $\mathrm{Ph}$. D. dissertation. Iowa State University. America, Iowa.

[2] Hymowitz, T. 1970. The domestication of the soybean. Economy Botany. 24: 408-421.

[3] Belay, A., 1987. Research programs of IAR (Institute of Agricultural research). Addis Ababa, Ethiopia.

[4] IAR (Institute of Agricultural Research). 1982. Soybean production guideline. A. A., Ethiopia.

[5] USDA (United States Department of Agriculture). 2016. World agriculture supply and demand estimates, WASDE-549. 
[6] Laswai, H. S., Mpanalile, J. J., Silayo, V. C. K. and Ballegu, W. R., 2005, November. Use of soybeans in food formulation in Tanzania. In Proceedings of the First National Soybean Stakeholders Workshop (pp. 10-11).

[7] Aoyagi, A. and Shurtleff, W., 2007. A Special Report on The History of Soybeans and Soy foods in Africa and Around the World. A Chapter from the Unpublished Manuscript, History of Soybeans and Soy foods, 1100.

[8] Chung, G. and Singh, R. J., 2008. Broadening the genetic base of soybean: a multidisciplinary approach. Critical Reviews in Plant Sciences, 27 (5), pp. 295-341.

[9] Anon. 1984. U.S. Soybean production and utilization. Soybean Research. Advance. Institute. DC. P. 69.

[10] Carter, T. E. and Wilson, R. F., 1998, September. Soybean quality for human consumption. Soybeans role in Australia. In Proceedings of the 10th Australian Soybean Conference'.(Ed. AT James) pp (pp. 1-16).

[11] LaRue, T. A. and Patterson, T. G., 1981. How much nitrogen do legumes fix?. In Advances in agronomy (Vol. 34, pp. 1538). Academic Press.

[12] LIU, K., 2000. Expanding soybean food utilization. Food Technol., 54, pp. 46-58.

[13] Liu, K., 2012. Soybeans: chemistry, technology, and utilization. Springer.

[14] Hymowitz, T., Collins, F. I., Panczner, J. and Walker, W. M., 1972. Relationship between the content of oil, protein, and sugar in soybean seed 1. Agronomy Journal, 64 (5), pp. 613-616.

[15] Wilcox, J. R. and Shibles, R. M., 2001. Interrelationships among seed quality attributes in soybean. Crop Science, 41 (1), pp. 11-14.

[16] Assefa, M. K., Hunje, R. and Koti, R. V. 2008. Enhancement of seed quality in soybean following priming treatment. Karnataka Journal of Agricultural Science. 23: 787-89.

[17] Rahman, M. M., Hossain, M. M., Anwar, M. P. and Juraimi, A S., 2011. Plant density influence on yield and nutritional quality of soybean seed. Asian Journal of Plant Sciences, 10 (2), p. 125.

[18] CSA (Central Statistical Agency). 2015. Agricultural Sample Survey 2012/2013: Report on area and production of crops (private peasant holdings, Meher season). Vol. III. Statistical bulletin. Addis Ababa, Ethiopia.

[19] Masuda, T. and Goldsmith, P. D., 2009. World soybean production: area harvested, yield, and long-term projections. International food and agribusiness management review, 12 (1030-2016-82753), pp. 1-20.

[20] AARC (Assosa Agricultural Research Center Farming system survey) 2007. Assosa, Ethioipa.

[21] ISTA (International Seed Testing Association). 1996. International Rules for Seed Testing. Seed Science and Technology, 1B288, Zurich, Switzerland.

[22] ISTA (International Seed Testing Association). 2003. International Rules for Seed Testing. 8303 Basserersdorf, CHSwitzerland.

[23] ISTA (International Seed Testing Association). 2008. International rules for seed testing.
[24] Czabator, F. J., 1962. Germination value: an index combining speed and completeness of pine seed germination. Forest science, 8 (4), pp. 386-396.

[25] Abdul-Baki, A. A. and Anderson, J. D., 1973. Vigor determination in soybean seed by multiple criteria. Crop science, 13 (6), pp. 630-633.

[26] ISTA (International Seed Testing Association). 1993. Hand book for seedling evaluation. International Seed Testing Association, Zurich, Switzerland.

[27] Maguire, J. D., 1962. Speed of Germination-Aid In Selection And Evaluation for Seedling Emergence And Vigor 1. Crop science, 2 (2), pp. 176-177.

[28] Qi-He, Y. A. N. G., Qi-He, Y. A. N. G., Wan-Hui, Y. E., Xiong, D. E. N. G., Hong-Ling, C. A. O., ZHANG, Y. and Kai-Yang, X. U., 2005. Seed germination eco-physiology of Mikania micrantha HBK. Botanical Bulletin of Academia Sinica, 46.

[29] Gomez, K. H. and Gomez, A. A. 1984. Statistical procedures for agricultural research. Second edition. Rice Research Institute. Pp 304-308.

[30] Sori, A., 2014. Effect of hydro and Osmo priming on quality of Chickpea (Cicer arietinum L.) Seeds. International Journal of Plant Breeding and Crop Science, 1 (2), pp. 028-037.

[31] Basra, S. M. A., Farooq, M., Afzal, I. and Hussain, M., 2006. Influence of osmopriming on the germination and early seedling growth of coarse and fine rice. Int. J. Agric. Biol, 8 (1), pp. 19-22.

[32] Harris, D., Joshi, A., Khan, P. A., Gothkar, P. and Sodhi, P. S., 1999. On-farm seed priming in semi-arid agriculture: development and evaluation in maize, rice and chickpea in India using participatory methods. Experimental Agriculture, 35 (1), pp. 15-29.

[33] Khairul Mazed, H. E. M. Najmul Haque Md., Israt Jahan Irin, Md. Ashraful Islam Pulok and Abu Habib, Md.. 2015. Effect of seed priming on growth, yield and seed quality. International Journal of multidisciplinary Research and Development. 2: 142-147.

[34] Zhang, F., Pan, B. and Smith, D. L., 1997. Application of gibberellic acid to the surface of soybean seed (t Glycine max (L.) Merr.) and symbiotic nodulation, plant development, final grain and protein yield under short season conditions. Plant and soil, 188 (2), pp. 329-335.

[35] Graf, E., Empson, K. L. and Eaton, J. W., 1987. Phytic acid. A natural antioxidant. Journal of Biological Chemistry, 262 (24), pp. $11647-11650$.

[36] Umair, A., Ali, S., Sarwar, M., Bashir, K., Tareen, M. J. and Malik, M. A., 2013. Assessment of some priming techniques in mungbean (Vigna radiata): a green house study. Pakistan Journal of Agricultural Research, 26 (4).

[37] Kiros, M. A. and Hunje, R., 2010. Seed priming for enhancing stand establishment, seed yield and quality of soybean. Karnataka J. Agric. Sci, 23, pp. 701-707.

[38] Afzal, I., Basra, S. M., Ahmad, N. A. Z. I. R., Cheema, M. A., Warraich, E. A. and Khaliq, A., 2002. Effect of priming and growth regulator treatments on emergence and seedling growth of hybrid maize (Zea mays L.). Int. J. Agric. Biol, 4, pp. 303-306. 
[39] Umair, A., Ali, S., Bashir, K. and Hussain, S., 2010. Evaluation of different seed priming techniques in mung bean (Vigna radiata). Soil and Environment, 29 (2), pp. 181-186.

[40] Mohammadi, G. R., 2009. The effect of seed priming on plant traits of late-spring seeded soybean (Glycine max L.). American-Eurasian Journal of Agricultural and Environmental Science, 5 (3), pp. 322-326.

[41] El-Saidy, A. E., Farouk, S. and El-Ghany, H. A., 2011. Evaluating of different seed priming on seedling growth, yield and quality componenets in two sunflower (Helianthus annuus L.) cultivars. Trends in Applied Sciences Research, 6 (9), pp. 977-991.

[42] Miraj, G., Shah, H. U. and Arif, M., 2013. Priming maize (Zea mays) seed with phosphate solutions improves seedling growth and yield. Journal of Animal and Plant Sciences, 23, pp. 893-899.

[43] Bolland, M. D. A. and Baker, M. J., 1988. High phosphorus concentrations in seed of wheat and annual medic are related to higher rates of dry matter production of seedlings and plants. Australian Journal of Experimental Agriculture, 28 (6), pp. 765-770.

[44] Zhang, M., Nyborg, M. and McGill, W. B., 1990. Phosphorus concentration in barley (Hordeum vulgare L.) seed: influence on seedling growth and dry matter production. Plant and Soil, 122 (1), pp. 79-83.

[45] THOMSON, C. and BOLGER, T., 2012, December. Effects of seed phosphorus concentration on the emergence and growth of. In Plant Nutrition-from Genetic Engineering to Field Practice: Proceedings of the Twelfth International Plant Nutrition Colloquium, 21-26 September 1993, Perth, Western Australia (Vol. 54, p. 353). Springer Science \& Business Media.

[46] Ros, C., Bell, R. W. and White, P. F., 1997. Effect of seed phosphorus and soil phosphorus applications on early growth of rice (Oryza sativa L.) cv. IR66. Soil Science and Plant Nutrition, 43 (3), pp. 499-509.

[47] Kathiresan, K., Kalyani, V. and Gnanarethinam, J. L., 1984. Effect of seed treatments on field emergence, early growth and some physiological processes of sunflower (Helianthus annuus L.). Field Crops Research, 9, pp. 215-217.

[48] Srivastava, M. K. and Dwivedi, U. N., 1998. Salicylic acid modulates glutathione metabolism in pea seedlings. Journal of Plant physiology, 153 (3-4), pp. 409-414.

[49] Mewael, K. A., Ravihunje 2008 Seed priming for enhancing stand establishment, seed yield and quality of soybean (Glycine max L.) in College of Agriculture, University of Agricultural Sciences, Dharwad-580 005, India. Karnataka Journal of Agriculture Science, 23 (5), pp. 701-707.

[50] Dornbos, D. L. 2002. Seed vigor. In seed quality: Basic Mechanisms and agricultural implications, Basra, A. s.,(ED.). CBS Publishers, New Delhi, India. Pp. 45-80.

[51] Sung, F., 1993. Biochemical activities associated with priming of sweet corn seeds to improve vigor. Seed Sci Technol, 21, pp. 97-105.

[52] Foti, S., Cosentino, S. L., Patane, C. and D'AGOSTA, G. M.,
2002. Effect of osmoconditioning upon seed germination of sorghum (Sorghum bicolor (L.) Moench) under low temperatures. Seed Science and Technology, 30 (3), pp. 521533.

[53] Sivritepe, N., Sivritepe, H. O. and Eris, A., 2003. The effects of $\mathrm{NaCl}$ priming on salt tolerance in melon seedlings grown under saline conditions. Scientia horticulturae, 97 (3-4), pp. 229-237.

[54] Karta, K. K., 2009. Seed vigor studies in vetches (ViciadasycarpaTen. and $V$. sativa $L$ ) from highlands of Ethiopia. AnM. Sc (Doctoral dissertation, Thesis presented to School of Graduate StudiesHaramaya University, Haramaya, Ethiopia. 51p).

[55] Copeland. L. O. and M. B. McDonald, 1995. Principles of Seed Science and Technology. 3rd edition. Chapman and Hall Press, New York, USA. 300p.

[56] Kurdikeri MB 1991. Studies on seed quality in hybrid maize (Zea mays L.). Ph. D. Thesis presented to University Agricultural Science, Bangalore, Karnataka, India.

[57] Steiner, J. J., 1990. Seed physiology, production and technology. Crop Science, 30: 1264-1271.

[58] GHASSEMI-GOLEZANI, K., Dalil, B., Muhammadi-Nasab, A. D. and Zehtab-Salmasi, S., 2008. The response of chickpea cultivars to field water deficit. Notulae Botanicae Horti Agrobotanici Cluj-Napoca, 36 (1), pp. 25-28.

[59] Taylor, A. G., Allen, P. S., Bennett, M. A., Bradford, K. J., Burris, J. S. and Misra, M. K., 1998. Seed enhancements. Seed science research, 8 (2), pp. 245-256.

[60] Karta K. Kalsa, Tomer R. P. S. \& Bekele Abebie 2011. Effects of storage duration and hydro-priming on seed germination and vigour of Common vetch. Journal of Science and Development 1 (1), 65-73.

[61] Ratajczak, K. and K. W. Duczmal, K. W. 1991. Seed vigor estimation by the conductometeric test, katedral Nasiennictwal I Szkolkarstwa Orgodniczego, AR, Poznan, Poland BiuletynInstytutu-Hodowali- Aklimatyzacji-Rozlin, 180: 381-390.

[62] Qasim, G., Malik, A. U., Sarfraz, M., Alias, M. A., Bukhsh, H. A. and Ishaque, M., 2010. Relationship between laboratory seed quality tests, field emergence and yield of chickpea. Crop Environ, 1, pp. 31-34.

[63] Wang, Y. R., Yu, L. and Nan, Z. B., 1996. Use of seed vigour tests to predict field emergence of lucerne (Medicago sativa). New Zealand Journal of Agricultural Research, 39 (2), pp. 255-262.

[64] Shovan, L. R., Bhuiyan, M. K. A., Sultana, N., Begum, J. A. and Pervez, Z., 2008. Prevalence of fungi associated with soybean seeds and pathogenicity tests of the major seed-borne pathogens. International Journal of Sustainable Crop Production, 3 (4), pp. 24-33.

[65] Mengistu, A. and Sinclair, J. B., 1979. Seed born microorganisms of Ethiopian-grown soybean and chickpea seeds. Plant Disease Reporter, 63 (7), pp. 616-619.

[66] Gorfu, D. and Sangchote, S., 2005. Fungi associated with field pea seeds from Ethiopia and seed transmission of Ascochyta pinodes. Seed Science and Technology, 33 (2), pp. 387-396. 